\title{
EFEITO DO HORMÔNIO DO CRESCIMENTO NA EXPRESSÃO GÊNICA DA SINTETASE DE ÁCIDOS GRAXOS EM ANIMAIS EM CRESCIMENTO
}

\author{
ANDREA A. F. BRASIL VIEIRA JOSÉ
}

Dissertação apresentada à Escola Superior de Agricultura "Luiz de Queiroz", Universidade de São Paulo, para obtenção do título de Mestre em Agronomia, Área de Concentração: Ciência Animal e Pastagens.

P I R A C I C A B A

Estado de São Paulo - Brasil

Julho -2000 


\title{
EFEITO DO HORMÔNIO DO CRESCIMENTO NA EXPRESSÃO GÊNICA DA SINTETASE DE ÁCIDOS GRAXOS EM ANIMAIS EM CRESCIMENTO
}

\author{
ANDREA A. F. BRASIL VIEIRA JOSÉ
}

Engenheira Agrônoma

Orientador: Prof. Dr. DANTE P. DUARTE LANNA

Dissertação apresentada à Escola Superior de Agricultura "Luiz de Queiroz", Universidade de São Paulo, para obtenção do título de Mestre em Agronomia, Área de Concentração: Ciência Animal e Pastagens.

P I R A C I C A B A

Estado de São Paulo - Brasil

Julho -2000 
Dados Internacionais de Catalogação na Publicação (CIP) DIVISÃO DE BIBLIOTECA E DOCUMENTAÇÃO - Campus “Luiz de Queiroz"/USP

José, Andrea A. F. Brasil Vieira

Efeito do hormônio do crescimento na expressão gênica da sintetase de ácidos graxos em animais em crescimento / Andrea A. F. Brasil Vieira José. - - Piracicaba, 2000.

p.

Dissertação (mestrado) - - Escola Superior de Agricultura Luiz de Queiroz, 2000.

Bibliografia.

1. Ácido graxo 2. Expressão gênica 3. Hormônio animal 4. Regulador de crescimento animal 5. Somatotropina 6. Suíno 7. Tecido adiposo I. Título

CDD 636.40892

\section{"Permitida a cópia total ou parcial deste documento, desde que citada a fonte - $\mathbf{O}$ autor"}


"O MEU CORAÇÃO FERVE COM PALAVRAS BOAS; FALO DO QUE TENHO FEITO NO TOCANTE AO REI; A MINHA LÍNGUA É A PENA DE UM DESTRO ESCRITOR”

(Sl 45,1).

Aos meus pais, Conceição e Jamil, a minha tia Clélia, minha sobrinha Carolina, meus irmãos e cunhada. Pela força e carinho que sempre me deram em todos os momentos da minha caminhada.

E, ao meu orientador e amigo Dante P. D. Lanna.

\section{E D I C O}


A autora manifesta seu profundo agradecimento,

A Deus, Mestre dos Mestres e Senhor, por tudo.

A todos do Laboratório de Biotecnologia Animal, Laboratório de Nutrição e Crescimento Animal e Departamento de Produção Animal pelo apoio e tempo despendido.

Ao meu orientador, Dante, pelos ensinamentos e incentivos. Ao Prof. Luiz Coutinho e a Lúcia Alvarez pela co-orientação, a Maria Antônia Ecthegaray, Cláudia Vitorello, Eduardo Delgado, Nirlei Javeno, Érica Elias Baron e demais integrantes de ambos os laboratórios pelo apoio, amizade e companheirismo.

Aos meu tios Dirceu - Rose Brasil Vieira, que sempre me apoiaram E a FAPESP que me deu subsídios para o desenvolvimento deste projeto. 


\section{SUMÁRIO}

\section{Página}

LISTA DE FIGURAS............................................................ vii

LISTA DE TABELAS................................................................ ix

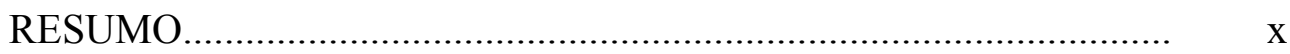

SUMMARY ............................................................................ xii

1. INTRODUÇÃO..................................................................... 1

2. REVISÃO DE LITERATURA................................................... 3

2.1. Importância do tecido adiposo................................................ 3

2.2. A somatotropina e o metabolismo do tecido adiposo................. 6

2.3. Somatotropina em animais em lactação e em crescimento......... 9

2.4. Expressão gênica da Sintetase de Ácidos Graxos..................... 11

2.5. RT-PCR Quantitativa Competitiva........................................ 14

3. MATERIAL E MÉTODOS....................................................... 17

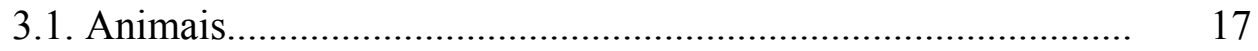

3.2. Obtenção da seqüência parcial da enzima FAS de suínos......... 17

3.2.1. Preparação de células competentes................................. 18

3.2.2. Transformação.............................................................. 18

3.2.3. Extração do DNA plasmidial........................................... 19

3.2.4. Seqüênciamento parcial do gene da FAS....................... 20

3.3. Construção dos "primers" para o gene da FAS......................... 20 
3.4. Extração de RNA total de tecido adiposo de suínos.................. 21

3.5. Reação de Transcrição Reversa................................................ 22

3.6. Otimização das condições de PCR .......................................... 22

3.7. Clonagem das seqüências nativa e competidora para o gene da 23 FAS.

3.7.1. Confirmação da identidade dos clones nativo e competidor................................................................. 25

3.7.2. Seqüênciamento dos clones nativo e competidor............. 25

3.8. Clonagem das seqüências nativa e competidora para o gene da

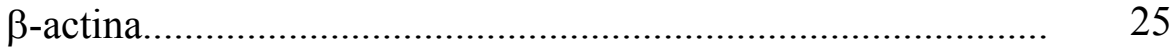

3.9. Culturas de tecido adiposo................................................... 27

3.9.1. Tratamentos das culturas de tecido adiposo..................... 27

3.9.2. Obtenção dos explantes de tecido adiposo....................... 28

3.9.3. Estabelecimento das culturas......................................... 28

3.9.4. Extração de RNA total..................................................... 29

3.9.5. Reação de Transcrição Reversa....................................... 29

3.10. Cálculos das diluições dos clones para curva padrão da FAS e da $\beta$-actina................................................................ 29

3.11. Quantificação da FAS e $\beta$-actina em suínos.......................... 30

3.12. Cinéticas de amplificação para a FAS e $\beta$-actina.................... 31

3.13. Curva padrão do gene da $\beta$-actina....................................... 32

3.14. Quantificação do gene da $\beta$-actina.......................................... 33

3.15. Curva padrão do gene da FAS............................................. 33

3.16. Quantificação do gene da FAS............................................ 34 
3.17. Ensaio da atividade enzimática da FAS................................. 35

3.18. Análises estatísticas............................................................ 35

4. RESULTADOS E DISCUSSÃO................................................ 36

4.1. Seqüência parcial da sintetase de ácidos graxos....................... 36

4.2. Seqüências dos clones nativo e competidor para o gene da 37

FAS.

4.3. Seqüências dos clones nativo e competidor para o gene da $\beta$ -

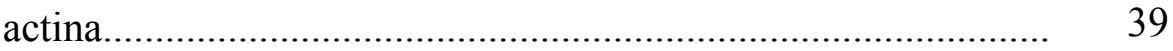

4.4. Cinéticas de amplificação para a FAS e $\beta$-actina....................... 40

4.5. Curvas padrões dos genes da FAS e $\beta$-actina........................... 42

4.6. Efeito da somatotropina na expressão gênica da FAS............... 45

4.7. Ensaio da atividade enzimática da FAS.................................. 49

5. CONCLUSÕES.................................................................... 54

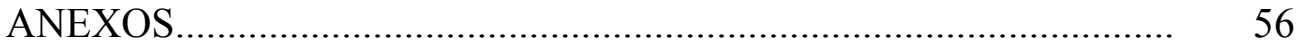

REFERÊNCIAS BIBLIOGRÁFICAS............................................. 60 


\section{LISTA DE FIGURAS}

Página

1. Seqüência parcial da enzima FAS de suínos. A seqüência parcial obtida foi de 340 (53-393) pares de base (bp)

2. Visualização em gel de agarose $3 \%$ da digestão com enzimas de restrição de três clones FAS nativo e competidor, comparados a um marcador de peso molecular (M) ø XHaeIII

3. Resultados dos seqüenciamentos dos clones FAS nativo e competidor

4. Resultados dos seqüenciamentos dos clones $\beta$-actina nativo e competidor.....

5. Representação gráfica das cinéticas de amplificação do gene da FAS na faixa de $10^{-3}$ fmoles e $\beta$-actina na faixa de $10^{-4}$ fmoles

6. Visualização em gel de agarose $3 \%$ corado com brometo de etídeo, da curva padrão do gene da FAS a $10^{-3} \mathrm{fmol}$, comparadas ao marcador de peso molecular (M); canaletas 1 : $25,6 \times 10^{-3}$ fmol; 2 : $12,8 \times 10^{-3}$ fmol; $\underline{3}: 6,4 \times$ $10^{-3} \mathrm{fmol} ; \underline{4}: 3,2 \times 10^{-3} \mathrm{fmol} ; \underline{5}: 1,6 \times 10^{-3} \mathrm{fmol} ; \underline{6}: 0,8 \times 10^{-3} \mathrm{fmol} ; \underline{7}: 0,4 \times$ $10^{-3} \mathrm{fmol} ; 8: 0,2 \times 10^{-3} \mathrm{fmol} ; \underline{9}: 0,1 \times 10^{-3} \mathrm{fmol}$; $\underline{10}$ : controle negativo..........

7. Representação gráfica da curva padrão para o gene da FAS na faixa de $10^{-3}$ fmoles. Os valores obtidos das áreas dos picos nativo e competidor, em 
cada faixa de diluição, foram plotados graficamente em escala

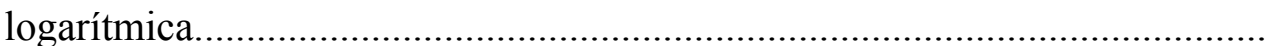

8. Visualização em gel de agarose $3 \%$ corado com brometo de etídeo, da curva padrão do gene da $\beta$-actina a $10^{-4}$ fmoles, comparadas ao marcador de peso molecular (M); canaletas $\underline{1}: 25,6 \times 10^{-4} \mathrm{fmol} ; \underline{2}: 12,8 \times 10^{-4} \mathrm{fmol} ; \underline{3}: 6,4 \times$ $10^{-4} \mathrm{fmol} ; \underline{4}: 3,2 \times 10^{-4} \mathrm{fmol} ; \underline{5}: 1,6 \times 10^{-4} \mathrm{fmol} ; \underline{6}: 0,8 \times 10^{-4} \mathrm{fmol} ; \underline{7}: 0,4 \times$ $10^{-4} \mathrm{fmol} ; 8: 0,2 \times 10^{-4} \mathrm{fmol} ; \underline{9}: 0,1 \times 10^{-4} \mathrm{fmol} ; \underline{10}$ : controle negativo...........

9. Representação gráfica da curva padrão para o gene da $\beta$-actina na faixa de $10^{-4}$ fmoles. Os valores obtidos das áreas dos picos nativo e competidor, em cada faixa de diluição, foram plotados graficamente em escala logarítmica

10. Visualização em gel de agarose $3 \%$ corado com brometo de etídeo, da quantificação de três animais, submetidos aos tratamentos com pST e controle para o gene da $\beta$-actina. As últimas canaletas representam o controle negativo.

11. Visualização em gel de agarose $3 \%$ corado com brometo de etídeo, da quantificação da FAS em três animais submetidos ao tratamento com pST e controle. As últimas canaletas representam o controle negativo 


\section{LISTA DE TABELAS}

Página

1. Efeito da somatotropina na abundância de mRNA, nas culturas de tecido adiposo, incubadas por $48 \mathrm{~h}$ na presença de diferentes

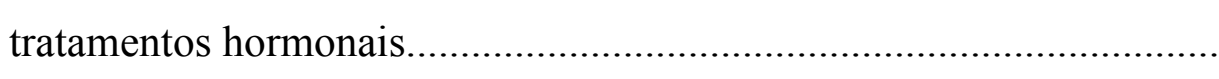

2. Efeito da somatotropina na atividade da FAS, nas culturas de tecido adiposo, incubadas por $48 \mathrm{~h}$ na presença de diferentes tratamentos

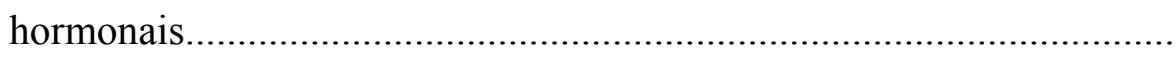




\title{
EFEITO DO HORMÔNIO DO CRESCIMENTO NA EXPRESSÃO GÊNICA DA SINTETASE DE ÁCIDOS GRAXOS EM ANIMAIS EM CRESCIMENTO
}

\author{
Autora: ANDREA A. F. BRASIL VIEIRA JOSÉ \\ Orientador: Prof. DANTE P. D. LANNA
}

\section{RESUMO}

A somatotropina (ST) pode reduzir a deposição de gordura em suínos, em crescimento em até $90 \%$. Este efeito parece ser função de diversas alterações no metabolismo do tecido adiposo, incluindo a redução na atividade da sintetase de ácidos graxos (FAS), considerada uma enzima limitante na via da síntese de lipídeos de novo. A atividade da FAS parece ser regulada principalmente através de alterações na abundância de seu mRNA, sendo fundamental conhecer os efeitos exercidos pela ST. Com este objetivo procurou-se validar o uso conjunto de duas técnicas: 1) o RT-PCR Quantitativo Competitivo (QC-RT-PCR), que permite monitorar a expressão gênica da FAS mesmo quando as concentrações de mRNA ou a quantidade de tecido são muito pequenas; e 2) uso de culturas de explantes de tecido adiposo, que permite submeter o tecido a um grande número de tratamentos. As culturas de longa duração possibilitam avaliar o efeito crônico da ST. Foram construídos "primers" para geração de um amplicon "nativo" de 307 bp e um "primer" anti-senso-deleção para amplificação de um 
fragmento de 243 bp denominado de "competidor". Em etapa subseqüente foram realizadas clonagens dos amplicons nativo e competidor que foram seqüenciados. Foi construída uma curva padrão, utilizando diluições seriais do DNA nativo e uma concentração constante do DNA competidor. Tecido adiposo de sete suínos, com peso médio de $78 \mathrm{~kg}$, foram retirados assepticamente e os explantes incubados em meio 199 na presença de insulina, dexametasona e antibióticos, com e sem ST recombinante suína (pST; Reporcin, Southern Cross Biotech), por 48 horas. O RNA total dos explantes foi extraído e, a partir destes, sintetizados os DNAs complementares (cDNA) à população de mRNAs. Os cDNAs foram amplificados pela PCR com "primers" específicos para a FAS capazes de amplificar também o fragmento nativo. Os resultados da amplificação foram avaliados utilizando-se a curva padrão citada. Os resultados, consistentes com a literatura, demonstraram uma redução da atividade enzimática da FAS em tecidos incubados por $48 \mathrm{~h}$ com pST, (46,4 vs 35,8 nmoles/mg.min; $\mathrm{P}<0,05)$. Consistente com os dados de atividade e dados da literatura, utilizando-se outras técnicas, observou-se redução de $40 \%$ na abundância de mRNA da FAS, em culturas de tecido adiposo, tratadas com somatotropina $(\mathrm{P}<0,05)$. Os resultados demonstram que o uso conjunto das técnicas de cultura primária de explantes por longo período e do QC-RT-PCR pode ser uma ferramenta para o estudo dos mecanismos envolvidos na modulação do metabolismo pela somatotropina no tecido adiposo. 


\title{
EFFECT OF GROWTH HORMONE ON FATTY ACID SYNTHASE GENE EXPRESSION IN GROWING ANIMALS
}

\author{
Author: ANDREA A. F. BRASIL VIEIRA JOSÉ \\ Adviser: Prof. DANTE P. D. LANNA
}

\section{SUMMARY}

In growing swine somatotropin (ST) treatment can reduce lipid deposition up to $90 \%$. This effect seems to be a function of a number of alterations in adipose tissue metabolism, and include reductions in fatty acid synthetase activity (FAS), a ratelimiting enzyme in the de novo pathway of lipid synthesis. Activity of FAS appears to be regulated primarily by alterations in mRNA abundance. Thus it is important to understand ST effects and this require an adequate test model. The present paper validated the combined use of two techniques: 1) RT-PCR quantitative competitive (QCRT-PCR), which allows monitoring gene expression of FAS even when very small quantities of tissue are available; and 2) use of cultures of adipose tissue explants, which allow to subject tissue samples to a large number of treatments. Long-term cultures allow evaluation of the chronic effects of somatotropin. Primers were constructed to generate a $307 \mathrm{bp}$ native amplicon and an anti-sense deletion primer allowed amplification of a 243 bp competitive sequence. Amplicons were subsequently cloned, 
fragments. Results from amplifications were evaluated using the standard curve developed earlier. Results, consistent with the literature, demonstrated a reduction in the enzymatic activity of FAS in adipose tissue incubated with pST for 48 hours (46,4 vs. 35,8 nmoles/mg.min; $\mathrm{P}<0,05)$. Consistent with the activity data, and literature data using other methodologies, we observed a 40\% reduction in FAS mRNA abundance in adipose tissue cultures treated with pST $(\mathrm{P}<0,05)$. Results demonstrate that the combined use of long-term primary cultures of adipose tissue explants and QC-RT-PCR can be a useful tool to study the mechanisms involved in somatotropin modulation of adipose tissue metabolism. 


\section{INTRODUÇÃO}

O homem tem buscado continuamente respostas e soluções para aumentar a produção de alimentos. Várias e importantes descobertas relacionadas à produção animal têm beneficiado produtores e consumidores que desejam produtos com melhor qualidade, segurança e a custos mais baixos. Com o advento da biologia molecular criourse um vasto campo para o desenvolvimento de novas tecnologias.

Algumas técnicas têm sido desenvolvidas para permitir a compreensão do metabolismo de nutrientes em animais domésticos. $\mathrm{O}$ entendimento do direcionamento de nutrientes para os diversos tecidos e a regulação do seu metabolismo intracelular é fundamental para compreensão de como podemos nutrir animais nos estádios de maior demanda fisiológica como gestação, lactação e crescimento acelerado. Este conhecimento também pode permitir a manipulação do metabolismo com objetivo de aumentar a produtividade e a eficiência de produção. Assim sendo, muito tem sido despendido no estudo destes sistemas e seus mecanismos de ação e regulação.

Em 1921, Evans e colaboradores descobriram que um extrato de pituitária bovina, quando injetado em ratos, estimulava o crescimento desses animais. Um grande número de trabalhos foram conduzidos nas décadas seguintes, quando se descobriu também que este extrato alterava a composição do tecido depositado, que passava a conter mais proteína e menos gordura. Em função dos efeitos observados, este fator presente no extrato foi denominado "hormônio do crescimento". A purificação do fator ocorreu duas décadas depois e o nome somatotropina utilizado para denotar a sua capacidade de estimular o crescimento. 
Após décadas de estudos dos efeitos fisiológicos da somatotropina, a pesquisa atual tem dado grande ênfase à compreensão dos efeitos dentro da célula. Diversos genes têm sua expressão regulada pela somatotropina. Dentre estes, estão incluídas importantes enzimas responsáveis pela síntese, deposição ou mobilização de proteína ou gordura. Dentre elas podemos citar a Acetil Coenzima A Carboxilase e a Sintetase de Ácidos Graxos que são importantes para a regulação da deposição de gordura em animais que utilizam carboidratos como fonte de carbono para a lipogênese.

Para melhor compreendermos os mecanismos pelos quais a somatotropina regula a expressão gênica, é necessário o desenvolvimento de um modelo animal que permita o estudo dos efeitos crônicos deste hormônio (que requerem horas ou dias para serem observados). Uma forma de conduzir estes experimentos seria a utilização de animais tratados por 2 a 14 dias com njeções diárias de somatotropina. Após este período biópsias de tecido adiposo seriam retiradas, sendo que animais controle teriam que ser usados. Problemas deste modelo são, os efeitos de variações individuais, o custo de manter os animais, o custo dos hormônios e, principalmente, o pequeno número de tratamentos que podem ser conduzidos. Uma técnica alternativa seria a cultura primária de tecido adiposo por longo período, em meio que garanta a viabilidade do tecido por períodos de 48 horas ou mais.

O efeito da somatotropina na expressão gênica, utilizando o modelo de tratamento in vivo, tem sido estudado com o uso da técnica de "northern blot", justamente em função da grande quantidade de tecido disponível. Para culturas de tecidos seria necessário desenvolver e validar uma técnica que requer pequena quantidade de tecido. Esta técnica de avaliação da expressão gênica seria a RT - PCR Quantitativa Competitiva ('Quantitative Competitive - Reverse Transcriptase Polimerase Chain Reaction") que foi estudada no presente trabalho.

O objetivo deste trabalho foi associar as técnicas de cultura de longa duração de explantes de tecido adiposo e QC-RT-PCR, desenvolvendo e validando um modelo de estudo do efeito da somatotropina sobre o metabolismo do tecido adiposo. 


\section{REVISÃO BIBLIOGRÁFICA}

\subsection{Importância do tecido adiposo}

Nos mamíferos, os nutrientes, absorvidos após a ingestão de alimentos e posterior digestão, são utilizados pelos tecidos envolvidos na manutenção e crescimento e no estabelecimento de reservas. As reservas de energia são armazenadas na forma de lipídeos; as reservas de glucose como glucogênio e os aminoácidos, armazenados como proteínas (Bauman \& Currie, 1980).

As bases fisiológicas das diferenças entre animais, quanto à eficiência de crescimento, estão relacionadas à partição dos nutrientes entre os processos de deposição de proteína muscular e lipídeo e ao potencial de crescimento do animal (Bauman et al., 1985). Esta partição de nutrientes envolve dois tipos de mecanismos de regulação: a homeostase e a homeorrese. O mecanismo de controle homeostático envolve a manutenção do equilíbrio fisiológico ou condições constantes no ambiente interno (e.g. manutenção da temperatura corporal). Com este objetivo os mecanismos homeostáticos atuam no curto prazo, sendo as respostas observadas em minutos ou segundos. Por sua vez o mecanismo de controle homeorrético pode ser representado pela orquestração ou controle coordenado no metabolismo dos diferentes tecidos corporais, coordenação esta necessária para dar suporte a um processo fisiológico dominante (Bauman \& Currie, 1980; Bauman, 1999).

A coordenação e mudanças no desenvolvimento do tecido adiposo, no final do período de gestação, são exemplos de mecanismos homeorréticos. Neste caso os nutrientes são preferencialmente direcionados para o tecido adiposo, permitindo a deposição das reservas corporais. Os controles homeorréticos, operam com particular importância, durante o início da lactogênese, quando o metabolismo do tecido adiposo é rapidamente alterado para suportar o novo estado físiológico (decréscimo na síntese e acréscimo na mobilização de lipídeos). No 
entanto, mecanismos de controle homeostáticos estão continuamente operando no animal com objetivo de manter o equilíbrio do meio interno em função de mudanças ambientais. Por exemplo, na manutenção dos níveis circulantes de metabólitos, ao longo do dia,que são alterados pelo consumo alimentar esporádico. Uma forma importante pela qual os mecanismos homeorréticos atuam envolve a modulação dos efeitos de sinais homeostáticos nos diferentes tecidos (Bauman \& Currie, 1980).

As reservas energéticas corporais estão predominantemente na forma de lipídeos, armazenadas no tecido adiposo. A deposição de reservas ocorre quando há um balanço positivo entre a taxa de síntese e a taxa de degradação de lipídeos no adipócito. Pelo lado da via bioquímica da síntese de gorduras, esta pode ocorrer de duas formas. Primeiro, a síntese de lipídeos pode ser feita a partir dos ácidos graxos pré-formados presentes nas dietas consumidas por diferentes animais. Nesta via uma enzima importante é a lipoproteína lipase, que facilita a absorção das gorduras ingeridas. O segundo mecanismo de síntese de lipídeos envolve a chamada síntese de novo, onde ácidos graxos são sintetizados a partir do acetato e butirato (nos ruminantes) e de carboidratos como a glucose (nos monogástricos). Em ambos os casos os ácidos graxos são esterificados a triglicerídeos que representam mais do que $95 \%$ das gorduras presentes no tecido adiposo branco.

O processo oposto, que junto com a síntese de ácidos graxos, controla a deposição de gordura, é a lipólise. Este processo, que ocorre no adipócito, envolve a hidrólise dos triglicerídeos depositados pelas vias metabólicas descritas acima.

A lipogênese e a lipólise são processos recíprocos no adipócito; assim, a regulação destes dois processos deve ser coordenada. Fatores, que afetam diretamente um processo, tendem a causar mudanças recíprocas no outro processo, via ação direta ou indireta. As relações temporais 
entre o metabolismo do tecido adiposo e o início da lactação têm sido muito estudados em várias espécies animais, devido a grande importância de se determinar como manter um balanço energético favorável ao animal durante todo período de lactação, gestação e produção. Da mesma forma estes processos têm sido intensivamente estudados, em animais em crescimento, pela sua importância em relação a fatores zootécnicos como a eficiência de produção e a qualidade da carne e fatores médicos como a obesidade.

O tecido adiposo desempenha, então, duas funções mais importantes: síntese e mobilização de lipídeos. O acréscimo, na taxa de lipídeos estocados, representa o balanço entre a síntese e mobilização de gordura. Em ruminantes, como em outras espécies, a importância relativa destes processos é dependente do balanço de entrada e requerimentos calóricos para as funções de manutenção e produção como crescimento e lactação (Bauman, 1976).

Nos animais domésticos a síntese de novo de lipídeos ocorre no próprio tecido adiposo, pela ação de enzimas lipogênicas ali presentes, exceto em aves em que a síntese de novo ocorre no fígado e no rato onde os ácidos graxos são sintetizados tanto no tecido adiposo como no fígado. Nos animais onde a síntese de lipídeos ocorre no fígado, os ácidos graxos resultantes têm que ser transportados para o tecido adiposo onde são reesterificados. Uma outra particularidade do ruminante está nas vias metabólicas utilizadas para geração do NADPH (dinucleotídeo de nicotinamidaadenina fosfato reduzido) requerido para a síntese de novo de lipídeos, o que pode implicar em diferentes mecanismos de regulação. Em termos de mobilização de gorduras, o ruminante também difere de espécies de laboratório na magnitude da resposta a hormônios homeostáticos lipolíticos (Vernon \& Finley, 1988). Estes fatos fazem do modelo experimental do bovino e do suíno algo bastante distinto do rato.

Em suínos em crescimento (e.g. em balanço positivo de energia), 80\% da síntese de gorduras é feita pela via de novo, utilizando glucose como substrato, função de baixa proporção das calorias 
( $>8 \%)$ da dieta na forma de ácidos graxos pré-formados. Nesta situação cerca de $40 \%$ da utilização de glucose pelo corpo é destinada para a deposição de lipídeos, que ocorre no próprio tecido adiposo (Etherton et al., 1995).

Algumas diferenças importantes são observadas no metabolismo dos diferentes depósitos de tecido adiposo (Bauman \& Vernon, 1993) inclusive com relação à resposta a hormônios. O tecido adiposo subcutâneo tem enorme importância agronômica, pois o excesso de gordura além de gerar problemas para a saúde humana (e.g. obesidade, diabetes, arteriosclerose, etc.) gera uma queda na eficiência econômica e aumento no custo ambiental. $\mathrm{O}$ custo energético, para deposição de tecido adiposo, é cerca de cinco vezes maior do que o da musculatura. Assim sendo, faz-se necessária a observação das adaptações no seu metabolismo, que possam ser reguladas pelo ambiente, condições nutricionais, hormonais e estado fisiológico.

\subsection{A somatotropina e o metabolismo do tecido adiposo}

A somatotropina ou "hormônio do crescimento" é um hormônio protéico, com 191 aminoácidos, sintetizado e secretado pela pituitária ou hipófise anterior. Dois peptídeos hipotalâmicos característicos, agem para estimular (fator liberador do hormônio do crescimento; GHRH) ou inibir (somatostatina) sua liberação da glândula pituitária (Tuggle et al., 1996).

A ST é essencial para o crescimento pós-natal e importante na regulação do metabolismo de

carboidratos, lipídeos, nitrogênio e minerais. Todos os mecanismos e tecidos alvos, envolvidos na ação da somatotropina, vêm sendo amplamente estudados, devido às suas influências no metabolismo animal. Segundo Bauman (1999), essas alterações no metabolismo envolvem efeitos crônicos, nos quais as alterações no metabolismo de diversos tecidos redirecionam os nutrientes para os tecidos corporais, desempenhando um papel central no controle homeorrético do metabolismo (Boyd \& Bauman, 1989).

Especificamente, dentre os efeitos de longo prazo, foram identificadas a redução na resposta do fígado e do tecido adiposo à insulina. Entretanto, este efeito da somatotropina não é o mesmo nos dois tecidos e esta especificidade é extraordinária. A somatotropina reduz a resposta antigluconeogênica à insulina no fígado, mas não o efeito antilipolítico no tecido adiposo. A somatotropina aumenta a 
resposta a beta-adrenérgicos e reduz a resposta à adenosina (Lanna et al., 1995). Outro sistema que pode ser alterado é o de transporte de glucose na membrana celular, com alterações na expressão gênica e na atividade específica do transportador de glucose GLUT4 (Bauman \& Vernon, 1993).

A economia de glucose é crítica em vacas de alta produção, onde a glucose é derivada primeiramente pela via da gluconeogênese hepática e com a glândula mamária utilizando grande quantidade (60-85\%) da glucose produzida. Em vacas, em lactação, o início do tratamento com ST causa um aumento no número de células mamárias e no uso de glucose. Este maior uso de glucose é acomodado por mudanças nos tecidos periféricos, como a já citada menor resposta do fígado à insulina, que resultam em acréscimo nas taxas de gluconeogênese hepática. Já a redução da resposta à insulina, nos tecidos periféricos, reduz a entrada e a oxidação da glucose nestes tecidos. Estas mudanças coordenadas na produção e utilização da glucose, são essenciais para manter a homeostase da glucose durante a transição do estado de vaca seca para um estado de intensa lactogênese (Bauman, 1999).

Trabalhos in vitro corroboram resultados in vivo, tendo sido observado que a somatotropina antagoniza o efeito estimulatório da insulina e da insulina mais dexametasona na síntese de ácidos graxos no tecido adiposo branco (Vernon \& Finley, 1988; Lanna \& Bauman, 1999), reduzindo a atividade total da Acetil Coenzima A Carboxilase (ACC) e a proporção da ACC no estado ativo (Vernon et al., 1991, Harris et al., 1993; Lanna et al., 1995). Este antagonismo, ou redução na habilidade da insulina em estimular a lipogênese, envolve um decréscimo na sensibilidade (ED 50) com nenhuma mudança na sua resposta máxima (Bauman, 1999). O resultado é uma inibição da utilização da glucose pelo tecido adiposo (Donkin et al., 1996a) e pelo fígado (Girard et al., 1997). O mecanismo envolvido nestas alterações parece incluir um efeito na transcrição de genes responsáveis pela síntese de lipídeos (Etherton et al., 1995, Donkin et al., 1996a, Girard et al., 1997). A habilidade da insulina em ativar a Acetil Coenzima A Carboxilase, no tecido adiposo de ovelhas lactantes, é impedida por um inibidor da transcrição deste gene. Isto implica que algum componente de sinalização na cascata traducional, envolvido na ativação desta enzima, tem que ser transcrito para que haja alteração na resposta à insulina. A somatotropina talvez exerça o seu efeito impedindo a produção de um suposto mediador (Vernon et al., 1991).

Borland et al., (1994), observaram que a administração da somatotropina, quando na ausência de outros hormônios, causou um decréscimo nas taxas de lipogênese apenas após 8 horas de incubação de culturas de tecido adiposo de ovelhas. Quando administrada com insulina e dexametasona, novamente decresceu a lipogênese, mas apenas após um intervalo de 12 horas. 
Ênfase principal tem sido dada na ação da somatotropina nos adipócitos, que são seus maiores alvos, pois ela age cronicamente para facilitar a lipólise e decrescer a síntese de lipídeos. Ainda que a somatotropina afete ambos os processos, de lipogênese e de lipólise, no tecido adiposo (Boyd \& Bauman, 1989), sua relativa importância depende do estado nutricional do animal. A redução na lipogênese é observada em animais em balanço positivo de energia, enquanto alterações nas taxas de lipólise são observadas em animais que iniciam o tratamento em balanço neutro ou negativo de energia (Bauman \& Vernon, 1993).

Dentre as enzimas que estão presentes nos adipócitos, a Sintetase de Ácidos Graxos (EC 2.3.1.85) e a Acetil Coenzima A Carboxilase (EC 6.4.1.2), são consideradas entre as mais importantes, isto porque mudanças nas atividades destas enzimas são paralelas às mudanças nas taxas de síntese de ácidos graxos (Sinnet-Smith et al., 1979). Isto sugere que estas sejam as enzimas responsáveis por controlar o fluxo desta via bioquímica de biossíntese dos ácidos graxos (Towle et al., 1997). A capacidade máxima de um tecido lipogênico carrear a síntese de novo de ácidos graxos é determinada pela concentração de enzimas lipogênicas neste tecido e esta concentração, por sua vez, parece ser, em grande parte, determinada pela quantidade de mRNA que codifica estas enzimas (Clarke, 1993).

Greenbaum (1953), citado por Etherton \& Louveau, (1992), foi o primeiro pesquisador a sugerir que a somatotropina estimula o catabolismo das gorduras. Mais recentemente uma série de estudos parece estar esclarecendo os mecanismos envolvidos. Inicialmente, imaginava-se que o aumento da lipólise era função de um aumento da resposta a beta-adrenérgicos e, posteriormente, demonstrou-se que este aumento é função de uma menor reposta à adenosina (Lanna et al., 1995) e uma menor atividade da proteína G inibitória (Bauman, 1999).

Em resumo, os efeitos da somatotropina sobre o adipócito são de enorme importância. Este efeito é direto, em função do fato de que os adipócitos apresentam receptores para a somatotropina. Apesar do adipócito ser um importante tecido alvo, é fundamental notar que os efeitos metabólicos da somatotropina, diretos e indiretos, têm a particularidade de envolver, de forma coordenada, uma grande variedade de tecidos e o metabolismo de todas as classes de nutrientes. 


\subsection{Somatotropina em animais em lactação e em crescimento}

Muitos trabalhos têm esclarecido que a administração de somatotropina em vacas lactantes, causa aumento na produção de leite e que, em suínos em crescimento, estimula o crescimento muscular e reduz a deposição de gordura. Devido aos resultados espetaculares destes estudos, um grande número de investigações foram conduzidas para examinar os mecanismos pelos quais a somatotropina afeta a lactação e o crescimento dos animais domésticos A somatotropina tem mostrado ter um expressivo efeito na partição de nutrientes entre o tecido muscular e o adiposo que conduz à uma dramática alteração no crescimento, principalmente em suínos (Etherton \& Bauman, 1998).

Administração diária de doses efetivas máximas de pST (> $100 \mu \mathrm{g} / \mathrm{kg}$ de peso vivo) em suínos em crescimento por 30-77 dias, pode causar um acréscimo no ganho diário de peso de aproximadamente 10-20\%, aumento da eficiência alimentar (e.g. proporção entre consumo alimentar e ganho de peso vivo) de 13-33\%, decréscimo na taxa lipogênica de aproximadamente 70-90\% e estímulo na deposição de proteína muscular em 35-62\% (Etherton et al., 1995, Etherton \& Bauman, 1998). Em termos aplicados, respostas, nestas magnitudes, têm enorme impacto na economicidade de produção e na qualidade da carcaça produzida.

Em geral, respostas do efeito da somatotropina no acréscimo de tecido magro têm sido menor em ruminantes em crescimento do que em suínos. Entretanto, estas diferenças podem ser em função de dificuldades em assegurar o suprimento de aminoácidos adequado em balanço e quantidade que permitam maximizar a resposta à ST. Quando o suprimento de proteína microbiana ruminal é completado com aminoácidos adicionais, que escapam da fermentação ruminal, o acréscimo em 
proteína de ruminantes tratados com ST é mais próximo àquele observado em suínos em crescimento.

O efeito da somatotropina na diminuição da utilização de glucose no tecido adiposo resulta em uma situação onde a glucose que é, normalmente, usada para lipogênese é redirecionada para outros tecidos, primeiramente o muscular. Esta adaptação metabólica é importante porque causa uma diminuição na hipertrofia dos adipócitos e, portanto, na taxa de acréscimo do tecido adiposo (Etherton \& Bauman, 1998). Entretanto, apesar deste menor uso de nutrientes pelo tecido adiposo, isto não quer dizer que estes nutrientes irão estimular a deposição de proteína. Na verdade, o consumo de alimentos por suínos é reduzido, uma vez que o decréscimo no uso de nutrientes pelo tecido adiposo é maior do que o aumento no uso de nutrientes pelo músculo.

A administração de somatotropina exógena causa enorme aumento na produção de leite não só em animais de laboratório, mas até em seres humanos (Bauman \& Vernon, 1993). No caso de animais domésticos, a resposta do tratamento com somatotropina, no aumento da produção de leite, foi demonstrado em bovinos, suínos, cabras e ovelhas, sendo a maioria das pesquisas realizadas com vaca em lactação. O padrão de resposta à administração de somatotropina, no tempo, envolve um aumento gradual na produção de leite nos primeiros cinco dias de tratamento com ST e atinge o máximo durante a primeira semana. Se o tratamento é interrompido, a produção de leite retorna gradualmente aos níveis do pré- tratamento em um período de tempo similar. Entretanto, quando o tratamento é continuado, o acréscimo na produção de leite é mantido. Por conseguinte, a somatotropina resulta num maior pico de produção e num acréscimo na persistência da curva de lactação (Etherton \& Bauman, 1998). 


\subsection{Expressão gênica da Sintetase de Ácidos Graxos}

A enzima sintetase de ácidos graxos (FAS) faz parte de uma classe de enzimas multifuncionais de propriedades espetaculares. A subunidade protéica desta multienzima tem um peso molecular de 260.000 kDa e contém, em um domínio separado, sete diferentes subunidades de atividade catalítica e um sítio para o grupo prostético, 4’ - fosfopanteteína, da proteína acil carreadora (Wakil, 1989).

Os ácidos graxos de cadeia longa são constituintes essenciais dos lipídeos da membrana e são importantes substratos para energia no metabolismo celular. O palmitato, que é o ácido graxo mais abundante no organismo animal, e é sintetizado de novo, inicialmente através da acetil coenzima A. Esta enzima carboxila o acetil coenzima A a malonil coenzima A. Posteriormente o malonil coenzima A e NADPH são utilizados para elongação da cadeia de ácido graxos por catálise mediada pela sintetase de ácidos graxos.

Em 1990, o gene da sintetase de ácidos graxos, incluindo todos os íntrons e exons, a região 3', e 2,5 kb (kilo bases) do promotor e seqüência 5', foi clonado. A partir daí, o objetivo tem sido identificar sequiências específicas no gene da sintetase de ácidos graxos cuja função é regular as taxas de transcrição em resposta a manipulações hormonais e de nutrientes (Clarke, 1997). Sua concentração no tecido é um papel determinante na capacidade máxima do tecido em sintetizar ácidos graxos através da via de novo (Clarke, 1993). Girard et al., (1997), conduziram uma série de estudos demonstrando o papel pivotal da FAS na regulação da síntese de gorduras ao longo do desenvolvimento de ratos e em função de alterações nas dietas fornecidas.

Segundo Girard et al., (1997) e Towle et al., (1997) dietas com alta quantidade de carboidratos simples e com baixa quantidade de gorduras conduzem, no fígado de mamíferos, uma indução de um conjunto de enzimas, que inclui a sintetase de ácidos graxos, envolvidas na lipogênese. Esta regulação parece ocorrer, em parte, através da ação de metabólitos intermediários sobre os fatores transcricionais que conduzem a uma elevação ou diminuição nas taxas de mRNA dessas enzimas chaves.

Dietas ricas em ácidos graxos polinsaturados não somente prejudicam a expressão da sintetase de ácidos graxos, em ratos adultos e em crescimento, como também impedem a elevação, de 20 a 30 vezes, nas taxas de mRNA associados com dietas com alta proporção de carboidratos fornecidas $a d$ libitum, em ratos sendo desmamados. A regulação da expressão gênica da FAS, por dietas com gorduras polinsaturadas, não ocorre somente para os genes da sintetase de ácidos graxos e S14, mas 
parece se estender para a acetil coenzima A carboxilase e glucose-6-fosfato desidrogenase. Essas dietas têm o efeito de suprimir as taxas de transcritos que codificam enzimas lipogênicas e este é um meio de decrescer a síntese destas enzimas, resultando na redução da capacidade lipogênica (Clarke \& Jump, 1993).

Além dos efeitos da dieta, outros mecanismos, como os hormonais, podem alterar a expressão de algumas enzimas chaves nos processos de síntese de lipídeos. Entre eles, a somatotropina parece ser um importante inibidor da expressão gênica (Bauman \& Vernon, 1993).

A administração de somatotropina pode diminuir a atividade enzimática da sintetase de ácidos graxos (Mildner \& Clarke, 1991; Donkin et al., 1996a; Wang et al., 1999). Wang et al., (1999) observaram, em culturas de tecido adiposo de suínos, que a habilidade da somatotropina em inibir a síntese de lipídeos requer mais de 4 horas para começar a se manifestar. Este intervalo reflete o tempo requerido para a somatotropina decrescer a abundância dos mRNAs envolvidos com a lipogênese, incluindo as enzimas que catalisam os processos finais ou de genes de proteínas componentes da via sinalizadora. As duas classes de genes parecem ter sua expressão gênica modulada pela ação da somatotropina.

A quantidade total da sintetase de ácidos graxos foi alterada após a incubação de tecido adiposo em culturas de 48 horas com somatotropina, embora este efeito não tenha sido muito grande (Lanna et al., 1994). Estes resultados são consistentes com dados da literatura indicando que alterações nas atividades da sintetase de ácidos graxos não deveriam ser esperadas em razão da meia vida desta enzima ser muito longa, de aproximadamente 48 horas. Isto indica que, embora ocorra uma redução relativamente rápida na abundância de mRNA desta enzima limitante, a redução da quantidade de proteína da sintetase de ácidos graxos no tecido adiposo requer mais tempo. O tratamento de longa duração com somatotropina in vivo (cerca de 7 dias) ou in vitro (culturas de pelo menos 48 horas) apresenta reduções maiores da lipogênese sugerindo que outros mecanismos também devem contribuir para a inibição da lipogênese no curto prazo (6-12 horas).

Segundo Donkin et al., (1996b), a primeira via pela qual a somatotropina antagoniza o efeito da insulina, seria através do bloqueio do estímulo da insulina na transcrição do gene da sintetase de ácidos graxos. Haveria um efeito líquido na diminuição da ativação de um ou de todos os "Elementos de Resposta à Insulina" (IREs) que atuam nas sequências promotoras do gene da FAS. 
A segunda é a que um elemento distinto no gene da FAS age como um elemento de controle negativo. Observou, também, que a administração de pST em ratos em crescimento, gerou uma redução de 55\% na abundância do mRNA da FAS, no fígado. Além disso, estes autores sugerem que os efeitos da somatotropina no fígado são específicos e não mediados por mudanças gerais na expressão de outros genes responsíveis à insulina.

Lee et al., (2000), observou que em explantes de tecido adiposo de suínos, que receberam pST por 4 semanas, a atividade enzimática da sintetase de ácidos graxos foi reduzida em $65 \%$. Condizente com outros resultados observados (Donkin et al., 1996a; 1996b, Harris et al., 1993; Lanna et al., 1995; Vernon et al., 1991), afirmam que o tratamento com pST reduz drasticamente a atividade da FAS, abundância de mRNA e um estudo sugere uma redução na estabilidade do mRNA (Yin et al., 1998). Estes estudos demonstram que estamos cada vez mais próximos de compreender as inter-relações entre a somatotropina, a insulina e a capacidade do tecido adiposo para sintetizar lipídeos. 


\subsection{RT-PCR Quantitativa Competitiva}

A técnica de Reação em Cadeia da Polimerase ou PCR permite, através de amplificação enzimática, a obtenção de um grande número de moléculas de ácidos nucléicos. Trata-se de uma metodologia revolucionária, com enorme gama de usos e que tem contribuído para o avanço da biologia molecular de forma espetacular. Devido ao caráter exponencial da amplificação do material, esta técnica pode comprometer os ensaios quantitativos já que os efeitos de pequena variação nas condições de reação, de amostra para amostra, são proporcionalmente amplificados durante o processo.

Para que estas variações sejam superadas, muitos autores têm usado moléculas recombinantes de DNA ou RNA como um padrão interno para ser adicionado, em diluições seriais conhecidas, antes da co-amplificação por PCR. Para obter uma eficácia igual na reação de Transcrição Reversa e PCR, o padrão e a molécula molde devem possuir alta homologia. Entretanto, a limitada resolução da eletroforese em gel de agarose, requer diferença significativa no tamanho e seqüência de nucleotídeos para separar as moléculas após a PCR. Para possibilitar maior resolução, um sistema de análise automático baseado na fluorescência induzida por laser, pode ajudar a superar estas dificuldades, pois permite que diferenças reduzidas no tamanho dos fragmentos sejam detectadas.

O uso quantitativo da PCR pode ser realizado com base em duas diferentes aproximações. Primeiro, um modelo matemático pode ser aplicado para estimar a concentração inicial da sequiência alvo de dados obtidos na fase exponencial e não exponencial ("plateau"). Para cada ensaio, muitas condições de amplificação por PCR (e.g. concentração de "primers" e número de ciclos), podem ser críticos e requerem cuidado na validação. Por esta razão muitos autores favorecem uma segunda 
abordagem em que adicionam um número conhecido das moléculas de padrão interno no tubo de reação e calculam o número de cópias iniciais pela relação entre molécula padrão e amostra obtidas após amplificação por PCR (Repp et al., 1995, Wang et al., 1989).

O uso da RT-CPR Quantitativa Competitiva (“Quantitative Competitive - Reverse Transcriptase - Polimerase Chain Reaction"), com um padrão interno de RNA ou DNA competidor, permite um meio de medir quantidades absolutas de transcritos de mRNA de um pequeno número de células. Estas são vantagens muito significativas sobre a técnica de northern blot. Muitos métodos de RT-PCR quantitativo competitivo requerem análises de múltiplas reações para determinar o ponto equimolar dos produtos produzidos do mRNA versus RNA competidor. O método que utiliza uma curva padrão para cada ensaio, com todas as amostras comparadas diretamente com essa curva, permite a detecção da atividade de genes específicos com grande precisão e menor número de reações. Isto é possível mesmo quando as quantidades disponíveis de tecido e concentração de RNA total são pequenas (e.g. tecido adiposo branco).

A curva padrão é produzida com diferentes amostras de RNA ou DNA (nativo) amplificada com quantidades constantes de DNA ou RNA competidor (Tsai \& Wiltbank, 1996). O procedimento é extremamente sensível na determinação de expressão gênica de determinadas enzimas, devendo haver muitos cuidados laboratoriais já que o método envolve a co-amplificação do DNA ou do RNA alvo com um padrão interno, utilizando a mesma sequiência de primers, mas gerando um produto de PCR de tamanho diferente. A validação do método é fundamental e foi feita com sucesso por diversos autores, sendo que uma discussão do processo de validação pode ser vista em Wang et al., (1989). 
Diversos exemplos do uso com sucesso desta técnica podem ser encontrados na literatura, incluindo a quantificação de amostras com limitada disponibilidade de RNA. Entre estes podemos citar trabalhos com avaliações do interferon-gama em suínos (Lessard et al., 1998), CFTR mRNA de endométrio humano (Mularoni et al.; 1996) e do mRNA da leptina, produto do gene ob, em culturas de adipócitos de ratos (Rentsch \& Chiesi, 1996). A literatura sugere que a técnica de QCRT-PCR pode ser utilizada com grande sucesso na avaliação de parâmetros da expressão gênica. 


\section{MATERIAL E MÉTODOS}

\subsection{Animais}

O modelo animal utilizado foram suínos Landrace $\mathrm{x}$ Large White, do Departamento de Produção Animal ESALQ-USP, de aproximadamente 78kg. Foram mantidos em baias individuais, onde receberam alimentação individual e adequada à fase de acabamento. $\mathrm{O}$ manejo destes animais foi de acordo com o normalmente utilizado pelo Departamento.

\subsection{Obtenção da seqüência parcial da enzima FAS de suínos}

A seqüência que codifica a enzima sintetase de ácidos graxos (FAS) de suínos, não estava disponível na literatura. Assim, foi realizado contato com pesquisadores do Departamento de Ciências Nutricionais da Universidade de Austin, no Texas, Mildner \& Clarke, (1991), que nos

cederam, gentilmente, um clone contendo um inserto de 1,2 Kb (kilo bases) correspondente à seqüência parcial da FAS de suínos clonada no plasmídeo BlueScript ${ }^{\circledR} \mathrm{M}^{\natural 3+}($ Stratagene), na concentração de $1 \mu \mathrm{g} / \mu \mathrm{l}$ de DNA. 


\subsubsection{Preparação de células competentes}

Células de Escherichia coli da linhagem JM109 foram tornadas competentes, segundo protocolo de Hanahan, (1983). As células foram semeadas em meio LB ágar (1\% de triptona, $0,5 \%$ de extrato de lêvedo, $0,5 \%$ de $\mathrm{NaCl}$ e $1,5 \%$ de ágar), contendo $10 \mathrm{mM}$ de $\mathrm{MgCh}$, e mantidas a $37^{\circ} \mathrm{C}$, "overnight". Foram coletadas colônias isoladas e incubadas em $5 \mathrm{ml}$ de meio SOB ( $2 \%$ de triptona, 0,5\% de extrato de lêvedo, $10 \mathrm{mM}$ de $\mathrm{NaCl}, 2,5 \mathrm{mM}$ de $\mathrm{KCl}, 10 \mathrm{mM}$ de $\mathrm{MgCh}, 10$ $\mathrm{mM}$ de $\mathrm{MgSO}_{4}$ ), $\mathrm{pH}$ 6,7-7,0, mantidas a $37^{\circ} \mathrm{C}, 200 \mathrm{rpm}$, "overnight". Transferiram-se $50 \mu \mathrm{da}$ cultura para $50 \mathrm{ml}$ de meio SOB que foi mantido a $37^{\circ} \mathrm{C}$, sob agitação, até D.O. $550 \mathrm{~mm}=0,5-0,6$. Foram adicionados $10 \mathrm{mM}$ de $\mathrm{MgCh}$ ao meio, que foi, então, mantido em banho de gelo por 15 minutos. Seguiu-se centrifugação por $10 \mathrm{~min}$., a $4^{\circ} \mathrm{C}$, e $5000 \mathrm{rpm}$. O "pellet" resultante foi ressuspendido em $10 \mathrm{ml}$ de RFI $(100 \mathrm{mM}$ de $\mathrm{KCl}, 10 \mathrm{mM}$ de $\mathrm{MnCh}, 30 \mathrm{mM}$ de acetato de potássio, $10 \mathrm{mM}$ de $\mathrm{CaCl}_{2} 2 \mathrm{H}_{2} \mathrm{O}$ e $15 \%$ de glicerol), mantido em banho de gelo por 15 minutos. Procedeu-se, então, centrifugação por 10 min., a $4^{\circ} \mathrm{C}$ e $3000 \mathrm{rpm}$. Finalmente, as células foram ressuspendidas em $2 \mathrm{ml}$ de RFII (10 mM de Na-MOPS, $10 \mathrm{mM}$ de $\mathrm{KCl}, 75 \mathrm{mM}$ de $\mathrm{CaCh}_{2} 2 \mathrm{H}_{2} \mathrm{O}$ e $15 \%$ de glicerol), e separadas em alíquotas de $100 \mu$ l, congeladas em $\mathrm{N}_{2}$ líquido e estocadas a $80^{\circ} \mathrm{C}$.

\subsubsection{Transformação}

O plasmídeo contendo a sequiência parcial da FAS foi diluído em TE (10 mM Tris $\mathrm{HCl}, \mathrm{pH}$ 8,0, 1 mM EDTA), para uma concentração final de $50 \mathrm{ng} / \mu \mathrm{l}$. Na transformação, $1 \mu \mathrm{l}$ desta diluição foi adicionado em $100 \mu \mathrm{l}$ de bactérias Escherichia coli da linhagem JM109 competentes. As células foram deixadas por 20 min. em banho de gelo, seguindo-se choque térmico a $42^{\circ} \mathrm{C}$ por $50 \mathrm{seg}$. e, posteriormente, deixadas em banho de gelo por 2 minutos. Foram adicionados $950 \mu 1$ de meio $\mathrm{SOB}$ às células e deixadas por $2 \mathrm{~h}$, a $37^{\circ} \mathrm{C}$ sob agitação. Após a transformação, foram plaqueados $100 \mu \mathrm{l}$ da cultura e o restante foi centrifugado e, posteriormente, adicionado em outra 
placa. O plaqueamento foi realizado em meio LB ágar contendo $50 \mu \mathrm{g} / \mathrm{ml}$ de ampicilina, 0,1 $\mathrm{mM} / \mathrm{ml}$ de IPTG e $40 \mu \mathrm{g} / \mathrm{ml}$ de X-Gal deixadas a $37^{\circ} \mathrm{C}$, "overnight".

\subsubsection{Extração do DNA plasmidial}

Em uma etapa subsequente, foi realizada extração do DNA plasmidial. Colônias isoladas foram incubadas em $5 \mathrm{ml}$ de meio $\mathrm{LB} \mathrm{pH}$ 7,5 (1\% de triptona, 0,5\% de extrato de lêvedo, 0,5\% de $\mathrm{NaCl}$ ), a $37^{\circ} \mathrm{C}, 250 \mathrm{rpm}$, "overnight". Foram coletados $1,5 \mathrm{ml}$ da cultura e centrifugados a 13000 rpm por 30 segundos. O sobrenadante foi descartado e o "pellet" resultante foi ressuspendido em $200 \mu \mathrm{l}$ de GET (25 mM de Tris $\mathrm{HCl}$ pH 8,0, 10 mM de EDTA pH 8,0). Foram adicionados $300 \mu \mathrm{l}$ de uma solução contendo $1 \%$ de SDS e $0,2 \mathrm{~N}$ de $\mathrm{NaOH}$, seguindo-se incubação em banho de gelo por 5 minutos. Posteriormente, foram adicionados $300 \mu \mathrm{l}$ de acetato de potássio $3 \mathrm{M}$ procedendose incubação em banho de gelo por 5 min. e, posteriormente, centrifugação à temperatura ambiente , $13000 \mathrm{rpm}$, por 10 minutos. O sobrenadante foi transferido para um novo tubo e adicionado, a ele, $10 \mathrm{mg} / \mathrm{ml}$ de RNAse A.

Foi feita incubação a $37^{\circ} \mathrm{C}$ por 30 min., seguida da adição de $400 \mu$ le clorofórmio, homogeneização e centrifugação a 13000 rpm, por 1 minuto. A fase superior foi coletada e a ela

adicionado o mesmo volume de iso-propanol absoluto, seguindo-se de centrifugação à temperatura ambiente, $13000 \mathrm{rpm}$ por 10 minutos. $\mathrm{O}$ sobrenadante foi descartado e adicionados $500 \mu \mathrm{l}$ de etanol 70\%. Foi realizada nova centrifugação, por 5 min., 1300 rpm. O "pellet" foi ressuspendido em $32 \mu \mathrm{l}$ de $\mathrm{H}_{2} \mathrm{O}_{\mathrm{MQ}}$. Foram adicionados $8 \mu \mathrm{l}$ de $\mathrm{NaCl} 4 \mathrm{M}$ e $40 \mu \mathrm{l}$ de PEG 13\% e mantidos em banho de gelo por 20 minutos. Seguiu-se centrifugação a $4^{\circ} \mathrm{C}, 13000 \mathrm{rpm}$, por 15 minutos. O sobrenadante foi removido e, ao "pellet" resultante, foram adicionados $500 \mu \mathrm{l}$ de 
etanol 70\%, centrifugado à temperatura ambiente, $13000 \mathrm{rpm}$, por 5 minutos. O "pellet" foi ressuspendido em $20 \mu \mathrm{l}$ de $\mathrm{H}_{2} \mathrm{O}_{\mathrm{MQ}}$.

\subsubsection{Seqüenciamento parcial do gene da FAS}

O DNA do clone contendo a seqüência parcial da FAS foi, então, seqüenciado usando o kit "BigDye Terminator Cycle Sequencing", em seqüenciador automático ABI 377 (Perkin Elmer).

\subsection{Construção dos "primers" para o gene da FAS}

A partir da seqüência parcial obtida, foram construídos "primers" senso (direto) e anti-senso (reverso) específicos com 20 pares de base (bp) cada, que foram sintetizados pela Operon Technologies, Inc. para a amplificação da seqüência de 307 bp, que foi denominada de "Nativa".

Foi construído, também, um "primer” anti-senso - deleção com 39 bp, para a amplificação de uma seqüência de 243 bp, que foi denominada de "Competidora". A seqüência deste "primer" foi desenhada de forma a conter, na sua extremidade 3', uma seqüência interna ao cDNA (DNA complementar ao mRNA da FAS) nativo e, na extremidade 5', a seqüência correspondente ao "primer" anti-senso utilizado na amplificação do cDNA nativo. Desta forma, foi possível manter a integridade das seqüências de ancoragem dos "primers" no cDNA competidor, mesmo gerando uma deleção de 64 bp na seqüência original (nativa) do cDNA. Assim, os "primers" senso e antisenso amplificam igualmente tanto o cDNA nativo quanto competidor.

A sequiência dos "primers" utilizados é apresentada a seguir:

\section{PRIMER SENSO}


5' CCTACTACATCGAGTGCATC 3';

PRIMER ANTI-SENSO

5' GGTATCAGCGCCTCCAGCAC 3';

\author{
PRIMER ANTI-SENSO - DELEÇÃO \\ 5' GGTATCAGCGCCTCCAGCACGCCTCGCAGCCGGGGGTCA 3'
}

\title{
3.4. Extração de RNA total de tecido adiposo de suínos
}

Explantes de 100 a 200 mg de tecido adiposo de suínos do Departamento de Produção Animal da ESALQ-USP foram retirados e, imediatamente, congelados em Nㅡ líquido, segundo Mildner \& Clarke, (1991). Posteriormente, foram macerados em um almofariz contendo $\mathrm{N}_{2}$ líquido para extração de RNA total.

Os explantes macerados foram dissolvidos em $750 \mu \mathrm{l}$ de Trizol (Gibco BRL) e $250 \mu \mathrm{lde}$ $\mathrm{H}_{2} \mathrm{O}_{\text {DEPC }}$ (água tratada com $0,01 \%$ de dietilpirocarbonato) e, posteriormente, incubados por 5 min a $15-30^{\circ} \mathrm{C}$, para permitir completa dissociação de complexos nucleoprotéicos. A seguir, foram adicionados $0,2 \mathrm{ml}$ de clorofórmio e agitados vigorosamente por 15 segundos. As amostras foram incubadas de 2 a 15 min. a $15-30^{\circ} \mathrm{C}$ e depois centrifugadas por 15 minutos. Após separação das fases, o RNA, que permaneceu na fase aquosa, foi precipitado com isopropanol e centrifugado. $\mathrm{O}$ "pellet" resultante foi lavado em etanol 75\%. Após a lavagem, o "pellet" foi ressuspendido com $\mathrm{H}_{2} \mathrm{O}_{\text {DEPC }}$ e a quantificação do RNA total foi feita em espectofotômetro (260 - $280 \mathrm{~nm}$ ). Os RNAs foram, então, submetidos à eletroforese em gel de agarose 1,5\% com formaldeído, em condições desnaturantes, para observar a integridade dos RNAs totais. 


\subsection{Reação de Transcrição Reversa}

Uma alíquota de $1 \mu \mathrm{g}$ do RNA total foi utilizada na síntese do DNA complementar (cDNA) à população de mRNAs. A síntese da primeira fita de cDNA foi catalisada pela enzima Transcriptase Reversa "Superscript Preamplification System" (Gibco BRL), utilizando-se como "primer" oligo(dT).

Na reação, utilizou-se uma alíquota de $1 \mu \mathrm{g}$ do RNA total e, 0,5 $\mu \mathrm{g}$ do "primer" oligo(dT), que permaneceram por $10 \mathrm{~min}$. a $80^{\circ} \mathrm{C}$, seguindo-se banho de gelo por 1 minuto. Foram adicionados 1X PCR buffer, 2,5 mM MgCh, $1 \mathrm{mM}$ dNTP mix e 0,01 M DTT, permanecendo 5 min. a $42^{\circ} \mathrm{C}$. Posteriormente, foi acrescentado $1 \mathrm{u} / \mu \mathrm{l}$ da enzima Transcriptase Reversa, permanecendo 50 min. a $42^{\circ} \mathrm{C}$ e $15 \mathrm{~min}$. a $80^{\circ} \mathrm{C}$. Foi adicionado $1 \mu \mathrm{l}$ de RNAse $\mathrm{H}$, procedendo-se incubação a $37^{\circ} \mathrm{C}$ por 20 minutos.

\subsection{Otimização das condições de PCR}

Após a síntese, o cDNA foi amplificado através de uma reação de PCR, onde foram utilizados 0,05 u/ $\mu \mathrm{l}$ da enzima Taq DNA polimerase, 1X PCR buffer, 1,5 mM MgCh, 0,2 mM dNTP e 10 pM/ $\mu 1$ dos "primers" senso e anti-senso para o gene da FAS. Para a amplificação da seqüência competidora, foram utilizados os mesmos reagentes nas mesmas quantidades, sendo que o "primer" anti-senso foi substituído pelo "primer" anti-senso - deleção. Os produtos amplificados, isto é, as sequiências nativa e competidora, foram submetidos à eletroforese em gel de agarose, corados em $1 \mu \mathrm{g} / \mathrm{ml}$ de brometo de etídeo e fotografados. O tamanho das bandas foi comparado a um marcador de peso molecular o $\varnothing \mathrm{X}$ HaeIII. 


\section{O PROGRAMA OTIMIZADO PARA A AMPLIFICAÇÃO CONSTA DAS SEGUINTES CONDIÇÕES:}

$\begin{array}{lll}1^{\circ} \text { ciclo } & 95^{\circ} \mathrm{C} & 5 \text { minutos } \\ & 57^{\circ} \mathrm{C} & 1 \text { minuto } \\ & 74^{\circ} \mathrm{C} & 1 \text { minuto } \\ & & \\ 2^{\circ} \text { ciclo }-34^{\circ} \text { ciclo } & 95^{\circ} \mathrm{C} & 1 \text { minuto } \\ & 57^{\circ} \mathrm{C} & 1 \text { minuto } \\ & 74^{\circ} \mathrm{C} & 1 \text { minuto } \\ 35^{\circ} \text { ciclo } & & \\ & 95^{\circ} \mathrm{C} & 1 \text { minuto } \\ & 57^{\circ} \mathrm{C} & 1 \text { minuto } \\ & 74^{\circ} \mathrm{C} & 10 \text { minutos }\end{array}$

\subsection{Clonagem das seqüências nativa e competidora para o gene da FAS}

A molécula nativa foi clonada utilizando-se como molde o plasmídeo, contendo a seqüência parcial da FAS, diluído para uma concentração final de $50 \mathrm{ng} / \mu \mathrm{l}$, que foram amplificados através de uma reação de PCR. Para a clonagem da molécula competidora, foi utilizado, como molde, 1 $\mu 1$ do produto de PCR, obtido a partir da reação de transcrição reversa descrita anteriormente.

As sequiências amplificadas foram, então, submetidas à eletroforese em gel de agarose $3 \%$. A confirmação da identidade dos fragmentos foi feita com a enzima $P v u I I$.

Posteriormente, os fragmentos de DNA foram eluídos do gel de agarose utilizando-se o Sephaglas ${ }^{\mathrm{TM}}$ Band Prep Kit (Pharmacia Biotech). Foram adicionados ao fragmento do gel, contendo o DNA, $250 \mu \mathrm{l}$ de solução solubilizadora de gel e $5 \mu \mathrm{l}$ de ácido acético. Seguiu-se incubação a $60^{\circ} \mathrm{C}$ por 10 minutos. Foram, então, adicionados $10 \mu \mathrm{l}$ de suspensão sílica, 
homogeneizados gentilmente e deixados 5 min. à temperatura ambiente. Posteriormente, foi feita centrifugação, removido o sobrenadante e adicionado $160 \mu \mathrm{l}$ de tampão de lavagem (20 mM de Tris $\mathrm{HCl}, \mathrm{pH} 8,0,1 \mathrm{mM}$ de EDTA, $0,1 \mathrm{mM}$ de $\mathrm{NaCl}$ com $18 \mathrm{ml}$ de etanol), ressuspendido novamente e repetida mais 2 vezes a lavagem. Foram adicionados $20 \mu 1$ de tampão de eluição (10 $\mathrm{mM}$ de Tris $\mathrm{HCl}, \mathrm{pH}$ 8,0, $1 \mathrm{mM}$ de EDTA), deixados 5 min. à temperatura ambiente com agitação vigorosa, centrifugado a $37^{\circ} \mathrm{C}, 13000 \mathrm{rpm}$ por 1 minuto. $\mathrm{O}$ sobrenadante foi removido e armazenado a $-20^{\circ} \mathrm{C}$.

Os produtos da eluição foram submetidos àeletroforese em gel de agarose $3 \%$. Foi realizada a quantificação do produto eluído e, posteriormente, foram realizadas, utilizando-se o SureClone Ligation Kit ${ }^{\mathrm{TM}}$ (Pharmacia Biotech), reações de "blunting/kinasing” onde foram adicionados $36 \mathrm{ng}$ de cada um destes produtos, 0,32 u/ $\mu 1$ de Klenow, $1 \mathrm{X}$ blunting/kinasing buffer, 0,47 u/ $\mu 1 \mathrm{de} \mathrm{T}_{4}$ Polynucleotide kinase para um volume final de reação de $20 \mu \mathrm{l}$. A reação foi homogeneizada gentilmente, centrifugada, mantida a $37^{\circ} \mathrm{C}$ por $30 \mathrm{~min}$. e adicionado $20 \mu \mathrm{l}$ de fenol:clorofórmio (1:1), centrifugada novamente e coletada a fase superior. Foi realizada, então, a purificação em coluna de "microspin", onde foram adicionados $500 \mu \mathrm{l}$ de resina na coluna centrifugada e o efluente foi removido. A coluna colocada em um novo tubo.

Os produtos obtidos na reação de "blunting/kinasing" foram, então, adicionados ao centro da coluna que foi centrifugada, $13000 \mathrm{rpm}$ por 1 minuto. $\mathrm{O}$ efluente foi removido para um novo tubo onde foi realizada a reação de ligação. Esta reação foi realizada adicionando-se $5 \mu 1$ do efluente, 2,5 ng de vetor desfosforilado $\left(\mathrm{pGEM}^{\circledR} 4 \mathrm{Z}_{(+)}\right.$, Promega, clivado com a enzima SmaI), 1X ligation buffer, 0,005 M DTT e 0,05 $\mu 1$ da enzima $\mathrm{T}_{4}$ DNA ligase. Misturada gentilmente e incubada a $16^{\circ} \mathrm{C}$ por 1 a 2 horas.

Posteriormente, bactérias Escherichia coli da linhagem JM109 foram transformadas, segundo protocolo descrito anteriormente, em que se utilizaram $10 \mu \mathrm{l}$ da reação de ligação da seqüência nativa e $10 \mu l$ da reação de ligação da seqüência competidora.

Foi realizado, então, o "screening" onde colônias de nativo e competidor cresceram em meio $\mathrm{LB}$ com $50 \mu \mathrm{g} / \mathrm{ml}$ de ampicilina, deixadas a $37^{\circ} \mathrm{C}, 250 \mathrm{rpm}$, "overnight". Posteriormente, foi realizada extração do DNA plasmidial, segundo protocolo descrito anteriormente, excluindo-se a precipitação com PEG $13 \%$. 


\subsubsection{Confirmação da identidade dos clones nativo e competidor}

A confirmação da identidade dos clones nativo e competidor foi estabelecida por clivagem com enzimas de restrição, onde a confirmação da natureza dos clones da FAS foi obtida através do tamanho dos fragmentos, após clivagem com a enzima EcoRI e HindIII.

\subsubsection{Seqüenciamento dos clones nativo e competidor}

O DNA foi, então, seqüenciado usando o kit "BigDye Terminator Cycle Sequencing", em seqüenciador automático ABI 377 (Perkin Elmer), para obtenção e confirmação das seqüências nativa e competidora.

Após confirmação, os clones contendo os insertos nos tamanhos e seqüências em pares de bases, esperados, foram estocados a $-80^{\circ} \mathrm{C}$.

\subsection{Clonagem das seqüências nativa e competidora para o gene da $\beta$-actina}

Devido a necessidade de utilização de um controle interno como fator de correção, houve necessidade de obtenção de clones nativo e competidor de um gene constitutivo.

A partir daí, foram clonadas seqüências nativa de 227 bp e competidora de 180 bp para o

gene da $\beta$-actina, a partir da seqüência que codifica o gene da $\beta$-actina de suínos, disponível no GeneBank (AF054837). Assim, foram construídos "primers" senso (direto) e anti-senso (reverso) específicos com 20 bp cada, que foram sintetizados pela Operon Technologies, Inc. gerando uma deleção de 47 bp na sequiência original (nativa) do cDNA. Esta construção dos "primers" foi realizada seguindo-se o mesmo princípio da utilizada para o gene da FAS. 
PRIMER SENSO

5'CTAGGCACCAGGGC GTCATG3';

PRIMER ANTI-SENSO

5'CTTAGGGTTCAGGGGGGCCT3';

\section{Primer Anti-Senso - Deleção \\ 5'CTTAGGGTTCAGGGGGGCCTTAGAAGGTGTGGTGCCAGA3'}

Todo o processo de clonagem das moléculas nativa e competidora, para o gene da $\beta$-actina, foi realizado, seguindo-se as mesmas etapas e protocolos utilizados para as clonagens das moléculas nativa e competidora para ao gene da FAS. Para a otimização das condições de PCR, foram utilizados $0,05 \mathrm{u} / \mu \mathrm{l}$ da enzima Taq DNA polimerase, $1 \mathrm{X}$ PCR buffer, 1,0 mM MgCh, 0,2 $\mathrm{mM}$ dNTP e $10 \mathrm{pM} / \mu \mathrm{l}$ dos "primers" senso e anti-senso para o gene da $\beta$-actina. Para a amplificação da sequiência competidora, foram utilizados os mesmos reagentes nas mesmas quantidades, sendo que o "primer" anti-senso foi substituído pelo "primer" anti-senso - deleção.

\section{O PROGRAMA OTIMIZADO PARA A AMPLIFICAÇÃO CONSTA DAS SEGUINTES CONDIÇÕES:}

$\begin{array}{lll}1^{\circ} \text { ciclo } & 95^{\circ} \mathrm{C} & 5 \text { minutos } \\ & 55^{\circ} \mathrm{C} & 1 \text { minuto } \\ & 74^{\circ} \mathrm{C} & 1 \text { minuto } \\ & & \\ & & \\ 2^{\text {o }} \text { ciclo }-34^{\circ} \text { ciclo } & 95^{\circ} \mathrm{C} & 1 \text { minuto } \\ & 55^{\circ} \mathrm{C} & 1 \text { minuto } \\ & 74^{\circ} \mathrm{C} & 1 \text { minuto } \\ 35^{\circ} \text { ciclo } & & \\ & 95^{\circ} \mathrm{C} & 1 \text { minuto } \\ & 55^{\circ} \mathrm{C} & 1 \text { minuto } \\ & 74^{\circ} \mathrm{C} & 10 \text { minutos }\end{array}$


A confirmação da identidade dos clones nativo e competidor foi estabelecida por clivagem com enzimas de restrição, onde a confirmação da natureza dos clones da $\beta$-actina foi obtida através do tamanho dos fragmentos, após clivagem com a enzima EcoRI e HindIII, e, posterior, seqüenciamento.

Após confirmação da identidade, os clones nativo e competidor para o gene da $\beta$-actina, foram estocados $\mathrm{a}-80^{\circ} \mathrm{C}$.

\subsection{Culturas de tecido adiposo}

\subsubsection{Tratamentos das culturas de tecido adiposo}

As culturas de tecido adiposo foram submetidas a dois tratamentos:

A) CONTROLE, contendo $100 \mathrm{ng} / \mathrm{ml}$ de insulina e $10 \mathrm{nM}$ de dexametasona;

B) SOMATOTROPINA, contendo $100 \mathrm{ng} / \mathrm{ml}$ de insulina, $10 \mathrm{nM}$ de dexametasona e $100 \mathrm{ng} / \mathrm{ml}$ de $\mathrm{pST}$.

(pSt: Reporcin, Southern Cross Biotech; insulina e dexametasona: Sigma Chemical Co).

\subsubsection{Obtenção dos explantes de tecido adiposo}

Sete suínos Landrace x Large White, do Departamento de Produção Animal ESALQ-USP, com peso médio de $78 \mathrm{~kg}$ foram abatidos e, aproximadamente, $20 \mathrm{~g}$ de tecido adiposo foram imediatamente colocados em um tampão de transporte (25 mM de HEPES; $0.15 \mathrm{M}$ de NaCl; 20U/ml de penicilina; $20 \mu \mathrm{g} / \mathrm{ml}$ de estreptomicina; $5 \mu \mathrm{g} / \mathrm{ml}$ de neomicina e $5 \mu \mathrm{g} / \mathrm{ml}$ de anfotericina B). Este tampão foi mantido a $37^{\circ} \mathrm{C}$ e pH 7,4. E, imediatamente, levados ao laboratório. 


\subsubsection{Estabelecimento das culturas}

Imediatamente, após o transporte até o laboratório, dentro da câmara de fluxo laminar, houve repetidas lavagens em tampão de transporte e, posteriormente, o tecido foi cortado com tesoura em vários explantes de aproximadamente $50 \mathrm{mg}$ e colocados no meio 199 (com sais de Earle's; L-glutamina; 25 mM de HEPES e 25 mM de bicarbonato de sódio; Sigma Chemical Co), com adição dos antibióticos (20U/ml de penicilina; 20 $\mu \mathrm{g} / \mathrm{ml}$ de estreptomicina; $5 \mu \mathrm{g} / \mathrm{ml}$ de neomicina e $5 \mu \mathrm{g} / \mathrm{ml}$ de anfotericina B), mantido a $37^{\circ} \mathrm{C}$ e $\mathrm{pH} 7,4$, de acordo com metodologia descrita por Lanna et al., (1995). Ao meio de cultura foram adicionados os hormônios de acordo com os tratamentos. Os explantes de tecido adiposo foram colocados em placas de cultura de 24 poços, contendo $2 \mathrm{ml}$ de meio 199, trocado a cada 24 horas. As placas foram mantidas em atmosfera de $5 \% \mathrm{CO}_{2}$, a $37^{\circ} \mathrm{C}$ por 48 horas. Após o período de incubação, explantes foram coletados, dentro da câmara de fluxo laminar e, imediatamente, submetidos à extração de RNA total, outros explantes, foram, imediatamente, congeladas em nitrogênio líquido e, estocados a $80^{\circ} \mathrm{C}$ para posterior ensaio da atividade enzimática.

\subsubsection{Extração de RNA total}

Os explantes coletados após o período de incubação, dentro da câmara de fluxo laminar, foram imediatamente submetidos à extração de RNA total, conforme descrito anteriormente e, posteriormente, à eletroforese em gel de agarose com formaldeído, em condições desnaturantes, para observar a integridade dos RNAs totais.

\subsubsection{Reação de Transcrição Reversa}

Uma alíquota de $1 \mu \mathrm{g}$ do RNA total foi utilizada na síntese do DNA complementar (cDNA) à população de mRNAs, através da Reação de Transcrição Reversa. 


\subsection{Cálculos das diluições dos clones para a curva padrão da FAS e da $\beta$-actina}

O uso do RT-PCR, com padrão interno de DNA ou RNA competidor, promove um meio de medir quantidades absolutas de transcritos de mRNA em uma peque na quantidade de células ou em explantes contendo quantidades mínimas de mRNA ou ainda de genes com baixa taxa de transcrição.

A curva padrão é produzida com diferentes amostras do DNA ou RNA desconhecido (nativo), amplificadas com uma quantidade constante do DNA ou RNA competidor (Tsai \& Wiltbank, 1996).

Foram calculados os pesos moleculares de cada clone nativo e competidor da FAS e da $\beta$ actina, em daltons, para se determinar qual é a concentração de cada DNA equivalente a 1

fentomole (fmol). Para a realização da curva padrão devem ser determinadas concentrações iguais em fmol do nativo e do competidor.

Um fentomole do clone FAS nativo eqüivale a 2,014 nanogramas (ng)de DNA, para o clone FAS competidor: 1 fmol eqüivale a 1,97 ng. Para o gene da $\beta$-actina, 1 fmol do clone nativo equiivale a 1,962 ng e o competidor a 1,930 ng. 


\subsection{Quantificação da FAS e $\beta$-actina em suínos}

Após serem feitos os cálculos para cada clone nativo e competidor para os genes da FAS e $\beta$ actina, foi realizada extração do DNA plasmidial., segundo protocolo descrito anteriormente, com precipitação com PEG 13\%. Posteriormente, foram realizadas diluições seriais do DNA FAS competidor, partindo-se de $1 \times 10^{-2}$ a $1 \times 10^{-4}$ fmol (fentomole), e para o gene da $\beta$-actina nas mesmas faixas de concentração. Estas diluições e, posteriormente, as subsequentes, foram realizadas em $\mathrm{H}_{2} \mathrm{O}_{\mathrm{MQ}}$ contendo $10 \mathrm{ng} / \mu \mathrm{l}$ de DNA carreador. Primeiramente, como DNA carreador foi utilizado o plasmídeo BlueScript $\mathrm{M}^{13+}$ (Stratagene), mas devido aos "primers" da $\beta$-actina se anelarem à sua seqüência, trocou-se o DNA carreador pelo plasmídeo pGEM ${ }^{\circledR} 4 Z$ (+) $($ Promega).

Seguindo-se de reações de PCR com $2 \mu 1$ de cDNA, de cada animal em cada tratamento, $1 \mu 1$ de cada diluição do DNA competidor; 0,05 u/ $\mu 1$ da enzima Taq DNA polimerase; 1X PCR buffer; 1,5 mM MgCh; 0,2 mM dNTP e $10 \mathrm{pM} / \mu 1$ dos "primers" senso fluorescente e anti-senso. Para o gene da $\beta$-actina seguiu-se o mesmo procedimento, substituindo-se, com $1 \mathrm{mM}$ de $\mathrm{MgCh}$ e com os "primers" específicos para o gene. Para o controle negativo foram adicionados todos os reagentes e $\mathrm{H}_{2} \mathrm{O}_{\mathrm{MQ}}$ ao invés dos DNAs. Foi utilizado o programa de PCR específico para cada gene.

Os produtos amplificados foram submetidos à eletroforese em gel de agarose $3 \%$, corados em brometo de etídeo e fotografados. O tamanho das bandas foi comparado a um marcador de peso molecular, $\varnothing \mathrm{X}$ Hae III.

Este procedimento foi realizado para se determinar a faixa de co-amplificação entre nativo (produto obtido através da RT-PCR a partir do RNA extraído da cultura de tecido adiposo de cada animal, em cada tratamento) e competidor. Observou-se, então, que as curvas padrões estariam nas faixas de concentrações para os genes da FAS de $10^{-3}$ fmoles e da $\beta$-actina na faixa de $10^{-4}$ fmoles. 


\subsection{Cinéticas de amplificação para a FAS e $\beta$-actina}

Para se determinar o número de ciclos de reação de PCR que será utilizado para a curva padrão, de cada gene, houve a necessidade de uma cinética de amplificação, onde se pode determinar em que ciclo ocorre a co-amplificação dos clones nativo e competidor, se as diluições de ambos estão equivalentes e para se determinar em que números de ciclos da PCR estará se iniciando a fase de "plateau".

Assim, após determinação da faixa de concentração de cada curva padrão, foram realizadas reações de PCR, com 45 ciclos, sendo coletadas as reações de 5 em 5 ciclos. Foram utilizados para o gene da FAS $1 \times 10^{-3} \mathrm{fmol} / \mu \mathrm{l}$ de DNA nativo e $1 \times 10^{-3} \mathrm{fmol} / \mu 1 \mathrm{de}$ DNA competidor; $0,05 \mathrm{u} / \mu \mathrm{l}$ da enzima Taq DNA polimerase; 1X PCR buffer; 1,5 mM MgCb; 0,2 mM dNTP e $10 \mathrm{pM} / \mu 1 \mathrm{dos}$ "primers" senso fluorescente e anti-senso. Para o gene da $\beta$-actina seguiu-se o mesmo procedimento, substituindo-se com 1,0 mM de $\mathrm{MgCh}$ e com os "primers" específicos para o gene, na faixa de concentração de $1 \times 10^{-4} \mathrm{fmol} / \mu \mathrm{l}$. Após a retirada dos tubos de reação do termociclador, de 5 em 5 ciclos, continuou-se a extensão a $74^{\circ} \mathrm{C}$, por $10 \mathrm{~min}$. em placa aquecedora. Para o controle negativo foram adicionados todos os reagentes e $\mathrm{H}_{2} \mathrm{O}_{\mathrm{MQ}}$ ao invés dos DNAs. Foi utilizado o programa de PCR específico para cada gene.

Posteriormente, foi retirada uma alíquota de $2 \mu$ de cada produto de PCR da FAS e da $\beta$ actina e, independentemente, adicionados a um tubo de reação com $3 \mu 1$ de "loading dye" e $1 \mu l$ do padrão interno de $150 \mathrm{bp}$, seguindo-se, então, de desnaturação a $95^{\circ} \mathrm{C}$ por 5 min. e, de centrifugação a $4^{\circ} \mathrm{C}$ por $30 \mathrm{seg}$, a $14000 \mathrm{rpm}$. Foram, então, submetidos à eletroforese em sequenciador automático (“Automated Laser Fluorescent DNA Sequencer - A.L.F. TM"”). 


\subsection{Curva padrão do gene da $\beta$-actina}

Após determinado o número de 34 ciclos, que seriam usados na reação de PCR, foram realizadas diluições seriais para o DNA nativo, partindo-se de $1 \times 10^{-3} \mathrm{fmol} / \mu 1$.

Realizaram-se diluições para se obter: diluição 1: $25,6 \times 10^{-4} \mathrm{fmol}$; $\mathrm{D}_{2}: 12,8 \times 10^{-4} \mathrm{fmol} ; \mathrm{D}_{3}$ :

$6,4 \times 10^{-4} \mathrm{fmol} ; D_{4}: 3,2 \times 10^{-4} \mathrm{fmol} ; D_{5}: 1,6 \times 10^{-4} \mathrm{fmol} ; D_{6}: 0,8 \times 10^{-4} \mathrm{fmol} ; D_{7}: 0,4 \times 10^{-4} \mathrm{fmol}$; $D_{8}: 0,2 \times 10^{-4}$ fmol e $D_{9}: 0,1 \times 10^{-4} \mathrm{fmol}$.

Posteriormente, foram realizadas reações de PCR, com 34 ciclos, onde o mix de PCR $(0,05$ $\mathrm{u} / \mu 1$ da enzima Ta $q$ DNA polimerase; 1 X PCR buffer; $1 \mathrm{mM} \mathrm{MgCb}$; 0,2 mM dNTP e $10 \mathrm{pM} / \mu 1$ dos "primers" senso fluorescente e anti-senso) contendo $1 \times 10^{-4}$ fmol de DNA competidor. Este mix foi distribuído em tubos de reação contendo $10 \mu \mathrm{l}$ de cada diluição $\left(\mathrm{D}_{1}\right.$ a $\left.\mathrm{D}_{9}\right)$ do DNA nativo. Para o controle negativo foram adicionados todos os reagentes e $\mathrm{H}_{2} \mathrm{O}_{\mathrm{MQ}}$ ao invés dos DNAs.

Foram realizadas duas curvas padrões para o gene da $\beta$-actina, partindo-se de diluições independentes, nas mesmas condições e, posteriormente, submetidas à eletroforese em gel de agarose, corados em $1 \mu \mathrm{g} / \mathrm{ml}$ de brometo de etídeo e fotografados. O tamanho das bandas foi comparado a um marcador de peso molecular o $\varnothing \mathrm{X} \mathrm{HaeIII.}$

Uma alíquota de $2 \mu 1$ de cada produto de PCR, foi adicionada a um tubo de reação com $3 \mu 1$ de "loading dye", desnaturada a $95^{\circ} \mathrm{C}$ por 5 min. seguindo-se de centrifugação a $4^{\circ} \mathrm{C}$ por 30 seg., a 14000 rpm. Foi, então, submetida à eletroforese em seqüenciador automático ("Automated Laser Fluorescent DNA Sequencer - A.L.F. $\left.{ }^{\text {TM"}}{ }^{\prime}\right)$. 


\subsection{Quantificação do gene da $\beta$-actina}

A quantificação do gene da $\beta$-actina, seguiu-se com reações de PCR, com 34 ciclos. Mix de PCR (0,05 u/ $\mu 1$ da enzima Taq DNA polimerase; 1X PCR buffer; $1 \mathrm{mM} \mathrm{MgCb}$; 0,2 mM dNTP e $10 \mathrm{pM} / \mu \mathrm{l}$ dos "primers" senso fluorescente e anti-senso) contendo $1 \mathrm{x} 10^{-4} \mathrm{fmol}$ de DNA competidor. Este mix foi distribuído em tubos de reação contendo $2 \mu 1$ de cada cDNAs dos explantes de cultura de tecido submetidos aos tratamentos. Para o controle negativo, foram adicionados todos os reagentes e $\mathrm{H}_{2} \mathrm{O}_{\mathrm{MQ}}$ ao invés dos DNAs. As quantificações foram realizadas em triplicatas.

Uma alíquota de $2 \mu 1$ de cada produto de PCR foi adicionada a um tubo de reação com $3 \mu 1$ de "loading dye", desnaturada a $95^{\circ} \mathrm{C}$ por 5 min. seguindo-se de centrifugação a $4^{\circ} \mathrm{C}$ por 30 seg., a 14000 rpm. Foi, então, submetida à eletroforese em sequenciador automático (“Automated Laser Fluorescent DNA Sequencer - A.L.F. ${ }^{\text {TM" }}{ }^{\prime}$.

\subsection{Curva padrão do gene da FAS}

Após determinação do número de 24 ciclos que seriam usados na reação de PCR, foram realizadas diluições seriais para o DNA nativo, partindo-se de 1 × $10^{-2} \mathrm{fmol} / \mu \mathrm{l}$.

Foram realizadas diluições para se obter: diluição 1: $25,6 \times 10^{-3} \mathrm{fmol} ; \mathrm{D}_{2}: 12,8 \times 10^{-3} \mathrm{fmol}$; $\mathrm{D}_{3}: 6,4 \times 10^{-3} \mathrm{fmol} ; \mathrm{D}_{4}: 3,2 \times 10^{-3} \mathrm{fmol} ; \mathrm{D}_{5}: 1,6 \times 10^{-3} \mathrm{fmol} ; \mathrm{D}_{6}: 0,8 \times 10^{-3} \mathrm{fmol}$; ; $: 0,4 \times 10^{-3}$ fmol; $\mathrm{D}_{8}: 0,2 \times 10^{-3}$ fmol e $\mathrm{D}_{9}: 0,1 \times 10^{-3} \mathrm{fmol}$.

Posteriormente, seguiram-se de reações de PCR, com 24 ciclos, a que se adicionou a um Mix de PCR (0,05 u/ $\mu 1$ da enzima Taq DNA polimerase; 1X PCR buffer; 1,5 mM MgCb; 0,2 mM dNTP e $10 \mathrm{pM} / \mu \mathrm{l}$ dos "primers" senso fluorescente e anti-senso) 1 x $10^{-3}$ fmol de DNA competidor. Este mix, como o DNA competidor, foi distribuído em tubos de reação contendo $10 \mu 1$ de cada diluição ( $\mathrm{D}_{1}$ a $\left.\mathrm{D}_{9}\right)$ do DNA nativo. Para o controle negativo foram adicionados todos os reagentes e $\mathrm{H}_{2} \mathrm{O}_{\mathrm{MQ}}$ ao invés dos DNAs. 
Foram realizadas duas curvas padrões para o gene da FAS, partindo-se de diluições independentes, nas mesmas condições e, posteriormente, submetidas a eletroforese em gel de agarose, corados em $1 \mu \mathrm{g} / \mathrm{ml}$ de brometo de etídeo e fotografados. O tamanho das bandas foi comparado a um marcador de peso molecular o $\varnothing \mathrm{X}$ Hae III.

Posteriormente, uma alíquota de $2 \mu \mathrm{l}$ de cada produto de PCR, foi adicionada a um tubo de reação com $3 \mu 1$ de "loading dye", desnaturada a $95^{\circ} \mathrm{C}$ por 5 min. seguindo-se de centrifugação a $4^{\circ} \mathrm{C}$ por 30 seg., a 14000 rpm. Foi, então, submetida à eletroforese em sequenciador automático (“Automated Laser Fluorescent DNA Sequencer - A.L.F. TM"”).

\subsection{Quantificação do gene da FAS}

A quantificação do gene da FAS, seguiu-se com reações de PCR, com 24 ciclos, onde o Mix (0,05 u/ $\mu 1$ da enzima Taq DNA polimerase; 1X PCR buffer; 1,5 mM MgCb;0,2 mM dNTP e 10 $\mathrm{pM} / \mu \mathrm{l}$ dos "primers" senso fluorescente e anti-senso) continha 1 x $10^{-3} \mathrm{fmol}$ de DNA competidor. Este mix foi distribuído em tubos de reação contendo $2 \mu 1$ de cada cDNA, obtido através de RTPCR dos RNAs extraídos das culturas de tecido adiposo dos suínos, em cada tratamento. Para o controle negativo foram adicionados todos os reagentes e $\mathrm{H}_{2} \mathrm{O}_{\mathrm{MQ}}$ ao invés dos DNAs. As quantificações foram realizadas em triplicatas.

Uma alíquota de $2 \mu \mathrm{l}$ de cada produto de PCR foi adicionada a um tubo de reação com $3 \mu 1$ de "loading dye", desnaturada a $95^{\circ} \mathrm{C}$ por 5 min., seguindo-se de centrifugação a $4{ }^{\circ} \mathrm{C}$ por 30 seg., a 14000 rpm. Foi, então, submetida à eletroforese em sequenciador automático (“Automated Laser

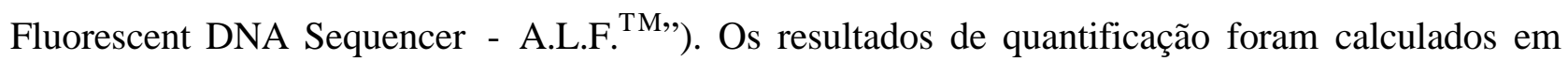
relação à curva padrão obtida para o gene da FAS. 


\subsection{Ensaio da atividade enzimática da FAS}

O ensaio da enzima FAS foi feito de acordo com Mellenberger et. al., (1973). Amostras de cultura de tecido adiposo subcutâneo submetidas aos tratamentos e estocadas a $-80^{\circ} \mathrm{C}$, foram utilizadas para o ensaio da atividade da FAS. Os explantes foram adicionados em tampão de homogeneização $(0,15 \mathrm{M} \mathrm{KCl}, 50 \mathrm{mM}$ de Tris base e Tris $\mathrm{HCl}, 1 \mathrm{mM}$ de Glutationa e $1 \mathrm{mM}$ de EDTA, pH 7,4), homogeneizados rapidamente em "politron", seguindo-se centrifugação a $4{ }^{\circ} \mathrm{C}$, $2000 \mathrm{~g}$ por $15 \mathrm{~min}$. Centrifugado, novamente, por $30 \mathrm{~min} ., 4^{\circ} \mathrm{C}$ e $27000 \mathrm{~g}$. O sobrenadante foi coletado e o ensaio determinado através da monitoração da transformação de NADPH (dinucleotídeo de nicotinamida-adenina fosfato reduzido) em NADP em incubações contendo substratos, cofatores e o homogenato do tecido adiposo, em cubetas sob espectofotômetro a 340 $\mathrm{nm}$.

O teor de proteína dos homogenatos foi determinado com Reagente Biureto (Gornall et. al., 1949) e as atividades expressas em nmoles/min.mg de proteína.

\subsection{Análises estatísticas}

A análise estatística foi realizada utilizando-se os valores de quantificação para o gene da $\beta$ actina, FAS, e FAS corrigidos para a abundância do mRNA da $\beta$-actina, em fentomoles. Utilizour-se o módulo de teste T pareado, do pacote estatístico Minitab (Minitab, versão 13, 2000). 


\section{Resultados e Discussão}

\subsection{Seqüiência parcial da sintetase de ácidos graxos}

O fragmento parcial da sintetase de ácidos graxos cedido por S.D. Clarke foi clonado e amplificado. O seqüenciamento parcial deste fragmento do gene da FAS de suínos foi conduzido e os resultados estão apresentados na figura 1.

\section{3}

CCGGTCTAGAGGATCCCCGGGTACCGAGCTCGAATTCCGGCCCCGCTGGA CAGCATCCAGAGCCTGGCCTCCTACTACATCGAGTGCATCAGACAGGTGC AGCCCGAGGGGCCTTACCGCATCGCCGGCTACTCTTACGGGGCCTGCGTG GCCTTCGAGATGTGCTCGCAGCTGCAGGCCCAGCAGAGCGCCACCCCCG GGAACCACAGCCTCTTCCTGTTCGACGGCTCACACACCTTCGTGCTGGCC TACACGCAGAGCGTCCGCGCTAAGATGACCCCCGGCTGCGAGGCCGAGG CCGAGGCCAAGGCCATGTACTTCTTCGTGCAGCAGTTCACCGACATGGAG CAAGGCAAGGTGCTGGAGGCGCTGATACCGCTCCAGGGCCTGGNAGCCG CGTGGCGGCACCGTGGACCTGATCACGCAGAGC 393

Figura 1 - Sequiência parcial da enzima FAS de suínos. A seqüência parcial obtida foi de 340 (53393) pares de base (bp). 


\subsection{Seqüiências dos clones nativo e competidor para o gene da FAS}

A partir da sequiência acima foram elaborados os "primers" senso, anti-senso e anti-sensodeleção. Os fragmentos nativo e competidor (com deleção) foram obtidos por PCR, utilizando-se os “primers" senso, anti-senso e anti-senso-deleção, respectivamente.

A confirmação da identidade dos clones nativo e competidor, para o gene da FAS, foi estabelecida por clivagem com enzimas de restrição, confirmando a natureza dos clones da FAS através do tamanho dos fragmentos, após clivagem com a enzima EcoRI e HindIII (Figura 2). Posteriormente, com o seqüenciamento no sequenciador automático ABI 377 obteve-se a confirmação das seqüências nativa e competidora demonstradas na figura 3 .

Os clones nativo e competidor obtidos, confirmaram a presença dos fragmentos nativo e competidor compatíveis com o tamanho e seqüência esperados. Verificourse a seqüência de ancoragem dos "primers" necessária para a confirmação do sucesso da clonagem, bem como a homologia dos fragmentos obtidos com a seqüência reportada (Figura 3). 


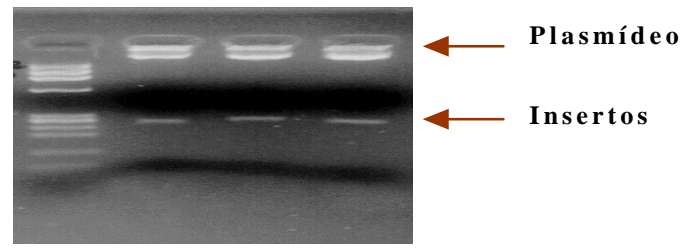

Figura 2 - Visualização em gel de agarose $3 \%$ da digestão com enzimas de restrição de três clones FAS nativo e competidor, comparados a um marcador de peso molecular (M) $\varnothing \mathrm{X} \mathrm{HaeIII.}$

Seqüência FAS nativa:

"Primer" senso

PLASMÍDEOCCCCCTACTACATCGAGTGCATCAGACAGGTGCAGCCCGAGG

GGCCTTACCGCATCGCCGGCTACTCTTACGGGGCCTGCGTGCCTTCGAGA TGTGCTCGCAGCTGCAGGCCCAGCAGAGCGCCACCCCCGGGAACCACAG CCTCTTCCTGTTCGACGGCTCACACACCTTCGTGCTGGCCTACACGCAGA GCGTCCGCGCTAAGATGACCCCCGGCTGCGAGGCCGAGGCCGAGGCCAA GGCCATGTACTTCTTCGTGCAGCAGTTCACCGACATGGAGCAAGGCAAGG TGCTGGAGGCGCTGATACCGGGGPLASMíDEO 
Seqüência FAS competidora:

"Primer" senso

PlASMídeOCCCCCTACTACATCGAGTGCATCAGACAGGTGCAGCCCGAGG GGCCTTACCGCATCGCCGGCTACTCTTACGGGGCCTGCGTGGCCTTCGAG ATGTGCTCGCAGCTGCAGGCCCAGCAGAGCGCCACCCCCGGGAACCACA GCCTCTTCCTGTTCGACGGCTCACACACCTTCGTGCTGGCCTACACGCAG AGCGTCCGCGCTAAGATGACCCCCGGCTGCGAGGCGTGCTGGAGGCGCT GATACCGGGGPLASMíDEO

“Primer" anti-senso - deleção

Figura 3 - Resultados dos sequienciamentos dos clones FAS nativo e competidor.

\subsection{Seqüência dos clones nativo e competidor para o gene da $\beta$-actina}

Assim como para o gene da FAS, após clonagem dos fragmentos nativo e competidor do gene da $\beta$-actina, foi realizada a confirmação da identidade dos clones através da clivagem com enzimas de restrição EcoRI e HindIII, onde a confirmação da natureza dos clones foi obtida através do tamanho dos fragmentos. Após a confirmação, por clivagem com as enzimas, foram seqüenciados no sequenciador automático ABI 377.

A confirmação dos clones nativo e competidor obteve-se com a presença dos fragmentos nativo e competidor compatíveis com o tamanho esperado. Verificou-se, também, a sequiência de ancoragem dos "primers", necessária para a confirmação da clonagem, bem como a homologia dos fragmentos obtidos com a seqüência obtida no GeneBank (Figura 4). 
Seqüência $\beta$-actina nativa:

\begin{abstract}
"Primer" anti-senso
PLASMíDEOCCCCTTAGGGTTCAGGGGGGCCTCCGTGAGCAGCACGGG GTGCTCCTCGGGGCCACGCGCAGCTCGTTGTAGAAGGTGTGATGCCAGAT CTTCTCCATGTCGTCCCAGTTGGTGACGATGCCGTGTTCGATGGGGTACTT GAGGGTCAGGATGCCCCGCTTGCTCTGAGCCTCGTCGCCCACGTAGCTGT CCTTCTGGCCCATGCCCACCATGACGCCCTGGTGCCTAGGGGGPLASMídeo

"Primer" senso
\end{abstract}

Seqüência $\beta$-actina competidora:

"Primer" senso

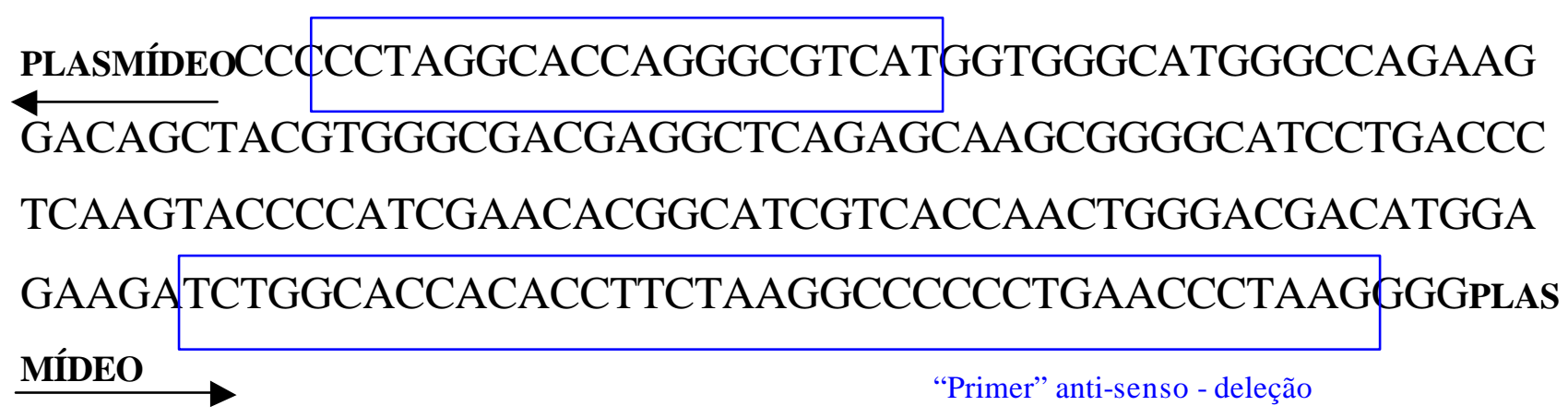

Figura 4 - Resultados dos seqüenciamentos dos clones $\beta$-actina nativo e competidor.

\title{
4.4. Cinéticas de amplificação para a FAS e $\beta$-actina
}

A figura 5 representa, graficamente, as cinéticas de amplificação dos genes da FAS e $\beta$ actina, respectivamente. Estes resultados foram obtidos plotando-se graficamente, em escala 
logarítmica, cada valor obtido das áreas dos picos (picos de fluorescência detectados no gel do A.L.F.) dos fragmentos nativo e competidor, a cada 5 ciclos de reação. (Anexos A e B).
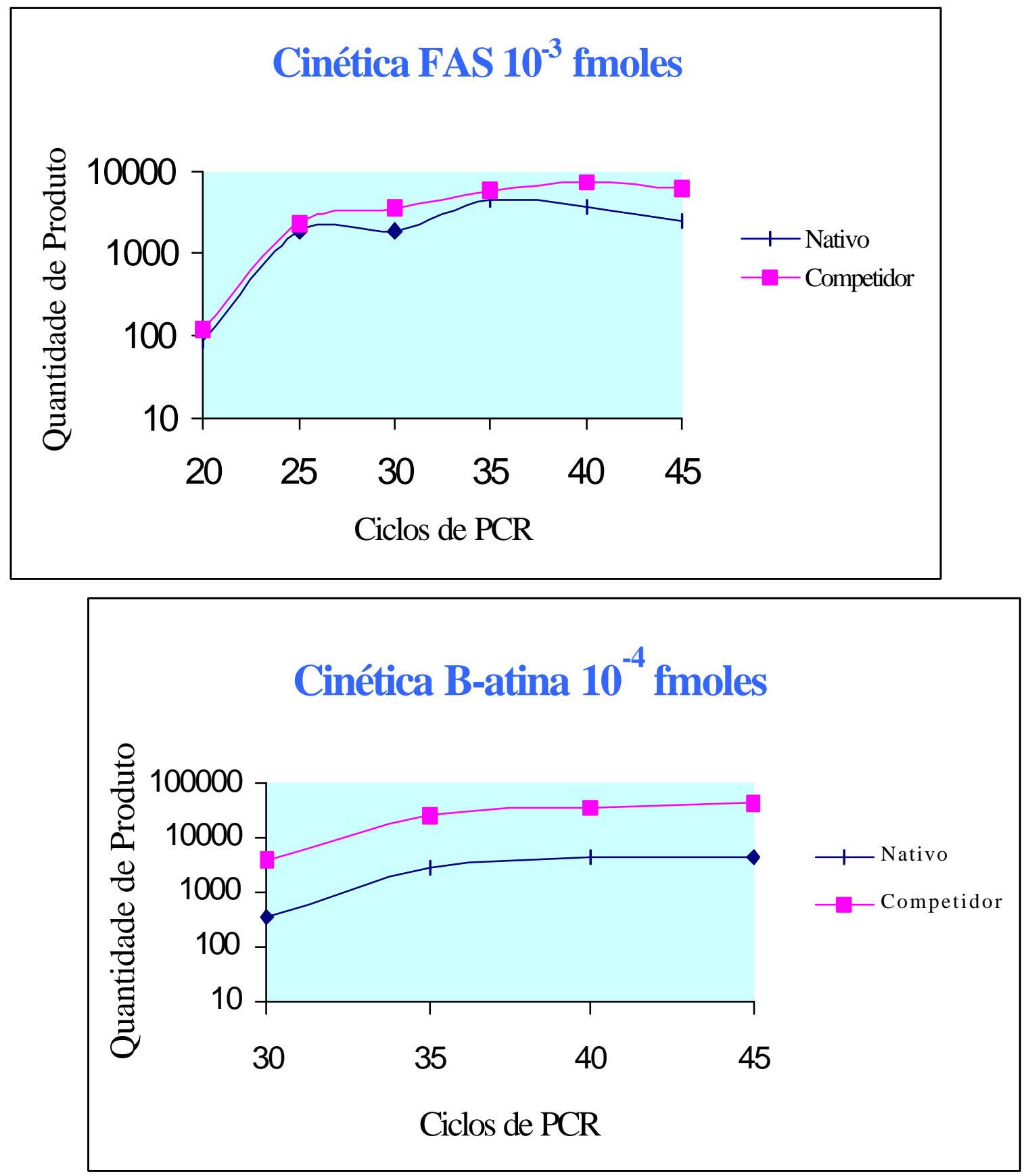

Figura 5 - Representação gráfica das cinéticas de amplificação do gene da FAS na faixa de $10^{-3}$ fmoles e $\beta$-actina na faixa de $10^{-4}$ fmoles. 
A cinética de amplificação é importante para verificar se o DNA nativo e competidor são amplificados com a mesma eficiência. Observa-se, para o gene da FAS, que a fase de "plateau" da reação de PCR inicia-se com 25 ciclos de reações. Assim, foi determinado um número de 24 ciclos para realização da curva padrão e quantificações. Para o gene da $\beta$-actina, a fase de "plateau" inicia-se com 35 ciclos; assim foram determinados 34 ciclos para as reações de curva padrão e quantificação para este gene.

Alguns autores sugerem que se deve trabalhar com um número de ciclos que proporcione bandas do nativo e competidor numa intensidade que possa ser quantificada, com precisão, pelo equipamento de imagem utilizado. Com um número alto de ciclos de PCR pode-se, também, favorecer a formação de heteroduplex e isto pode gerar um sério confundimento nos resultados com o método de eqüimolaridade (Tsai \& Wiltbank, 1996).

\subsection{Curvas padrões do genes da FAS e $\beta$-actina}

Os produtos das reações de PCR, com diferentes quantidades dos fragmentos nativo da FAS, foram submetidas à eletroforese em gel de agarose $3 \%$ corado em $1 \mu \mathrm{g} / \mathrm{ml}$ de brometo de etídeo. A fotografia do gel, apresentada na figura 6, ilustra os resultados obtidos. Posteriormente, os produtos da reação foram novamente submetidos à eletroforese, desta vez em sequenciador automático A.L.F. (Anexo C).

Os resultados da curva padrão, para o gene da FAS, estão representados graficamente, na figura 7, onde os valores de cada pico do fragmento nativo e competidor (obtido no A.L.F.), em cada faixa de diluição, foram plotados graficamente em escala logarítmica. Ambas as curvas resultaram em altos

valores de $\mathrm{R}^{2}$ e equações de regressão praticamente idênticas. Em função dos resultados, uma equação média foi estabelecida. 


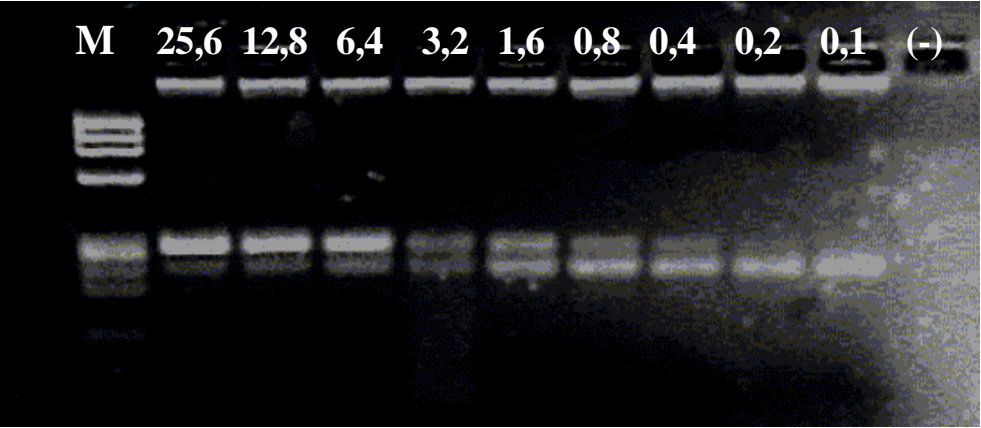

Figura 6 - Visualização em gel de agarose 3\% corado com brometo de etídeo, da curva padrão do gene da FAS a $10^{-3}$ fmol, comparadas ao marcador de peso molecular (M); canaletas $1: 25,6 \mathrm{x}$ $10^{-3} \mathrm{fmol} ; \underline{2}: 12,8 \times 10^{-3} \mathrm{fmol} ; \underline{3}: 6,4 \times 10^{-3} \mathrm{fmol} ; \underline{4}: 3,2 \times 10^{-3} \mathrm{fmol} ; \underline{5}: 1,6 \times 10^{-3} \mathrm{fmol} ; \underline{6}$ : $0,8 \times 10^{-3} \mathrm{fmol} ; \underline{7}: 0,4 \times 10^{-3} \mathrm{fmol} ; 8: 0,2 \times 10^{-3}$ fmol; $\underline{9}: 0,1 \times 10^{-3}$ fmol.; $\underline{10}$ : controle negativo.

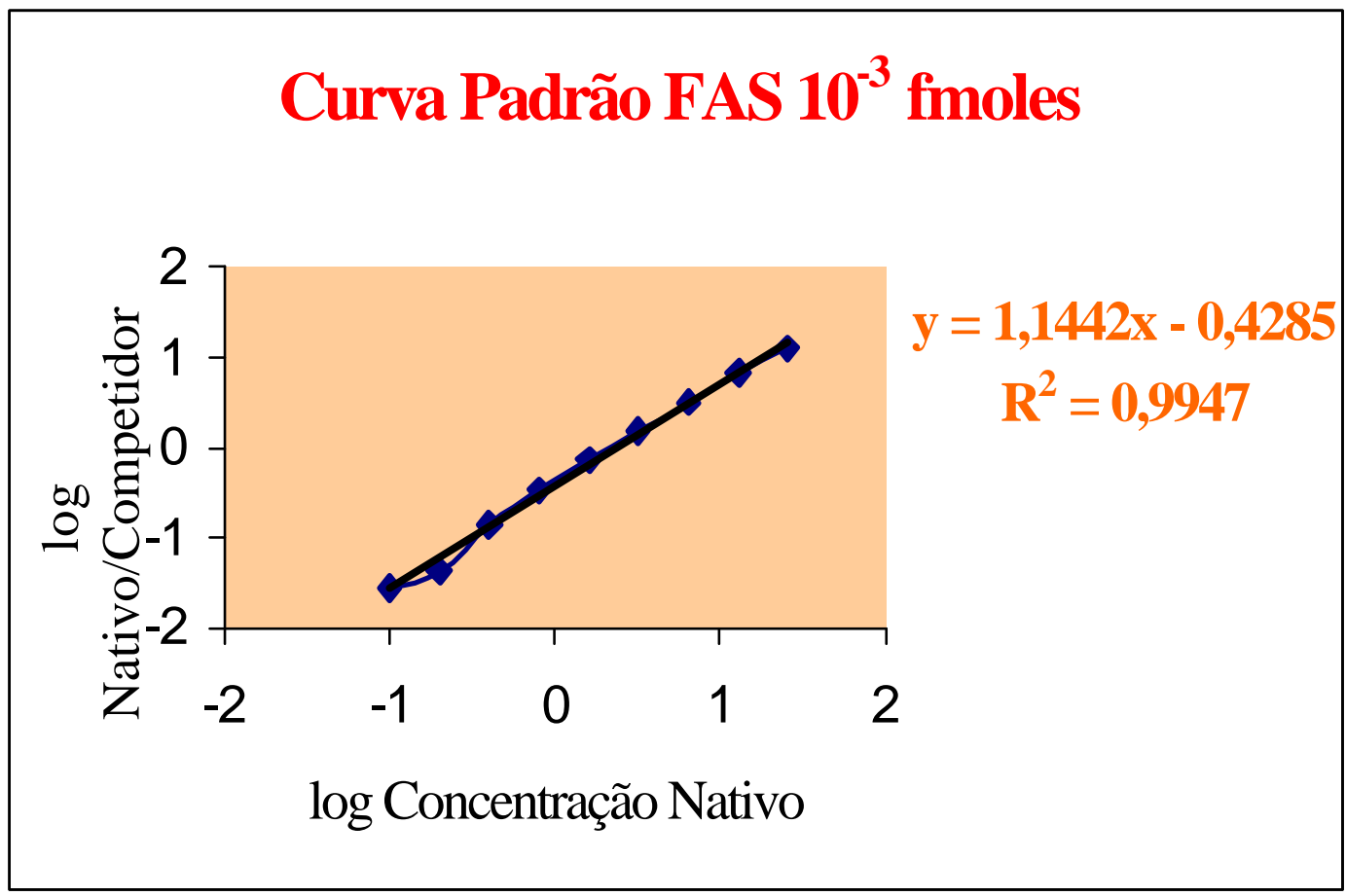

Figura 7 - Representação gráfica da curva padrão para o gene da FAS na faixa de $10^{-3}$ fmoles. Os valores obtidos das áreas dos picos nativo e competidor, em cada faixa de diluição, foram plotados graficamente em escala logarítmica.

Da mesma forma que para o gene da FAS, os produtos do PCR, obtidos para o gene da $\beta$ actina, foram submetidos à eletroforese em gel de agarose $3 \%$, corados em $1 \mu \mathrm{g} / \mathrm{ml}$ de brometo de 
etídeo e fotografados. O tamanho das bandas foi comparado a um marcador de peso molecular o $\varnothing$ X Hae III (Figura 8).

Posteriormente, uma alíquota de $2 \mu \mathrm{l}$ de cada produto de reação foi novamente submetida à eletroforese, desta vez em sequenciador automático A.L.F. (Anexo D).

Os resultados da curva padrão para o gene da $\beta$-actina estão representados graficamente na figura 9, onde os valores de cada pico do fragmento nativo e competidor (obtido no A.L.F.), em cada faixa de diluição, foram plotados graficamente em escala logarítmica. Como observado com o gene da FAS, foi utilizada uma equação média devido à obtenção de equações de regressão similares e com alto coeficiente de determinação $\left(\mathrm{R}^{2}\right)$, na duplicata do ensaio.

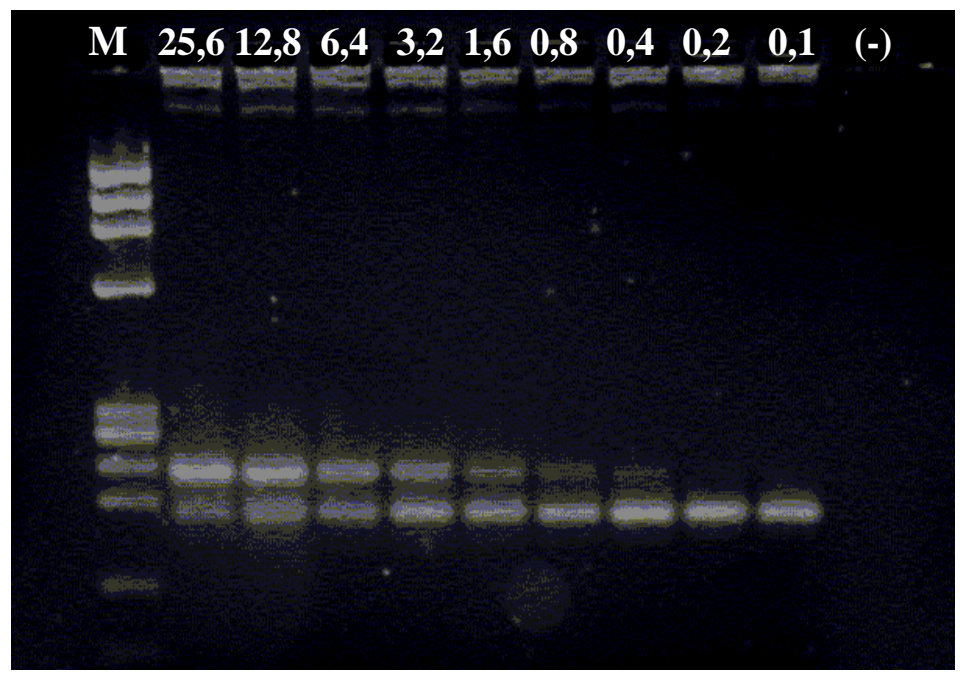

Figura 8 - Visualização em gel de agarose 3\% corado com brometo de etídeo, da curva padrão do gene da $\beta$-actina a $10^{-4}$ fmoles, comparadas ao marcador de peso molecular (M); canaletas $\underline{1}$ : $25,6 \times 10^{-4} \mathrm{fmol} ; 2: 12,8 \times 10^{-4} \mathrm{fmol} ; \underline{3}: 6,4 \times 10^{-4} \mathrm{fmol} ; \underline{4}: 3,2 \times 10^{-4} \mathrm{fmol} ; \underline{5}: 1,6 \times 10^{-4}$ fmol; $\underline{6}: 0,8 \times 10^{-4} \mathrm{fmol} ; \underline{7}: 0,4 \times 10^{-4} \mathrm{fmol} ; 8: 0,2 \times 10^{-4} \mathrm{fmol} ; \underline{9}: 0,1 \times 10^{-4} \mathrm{fmol} ; \underline{10}$ : controle negativo. 


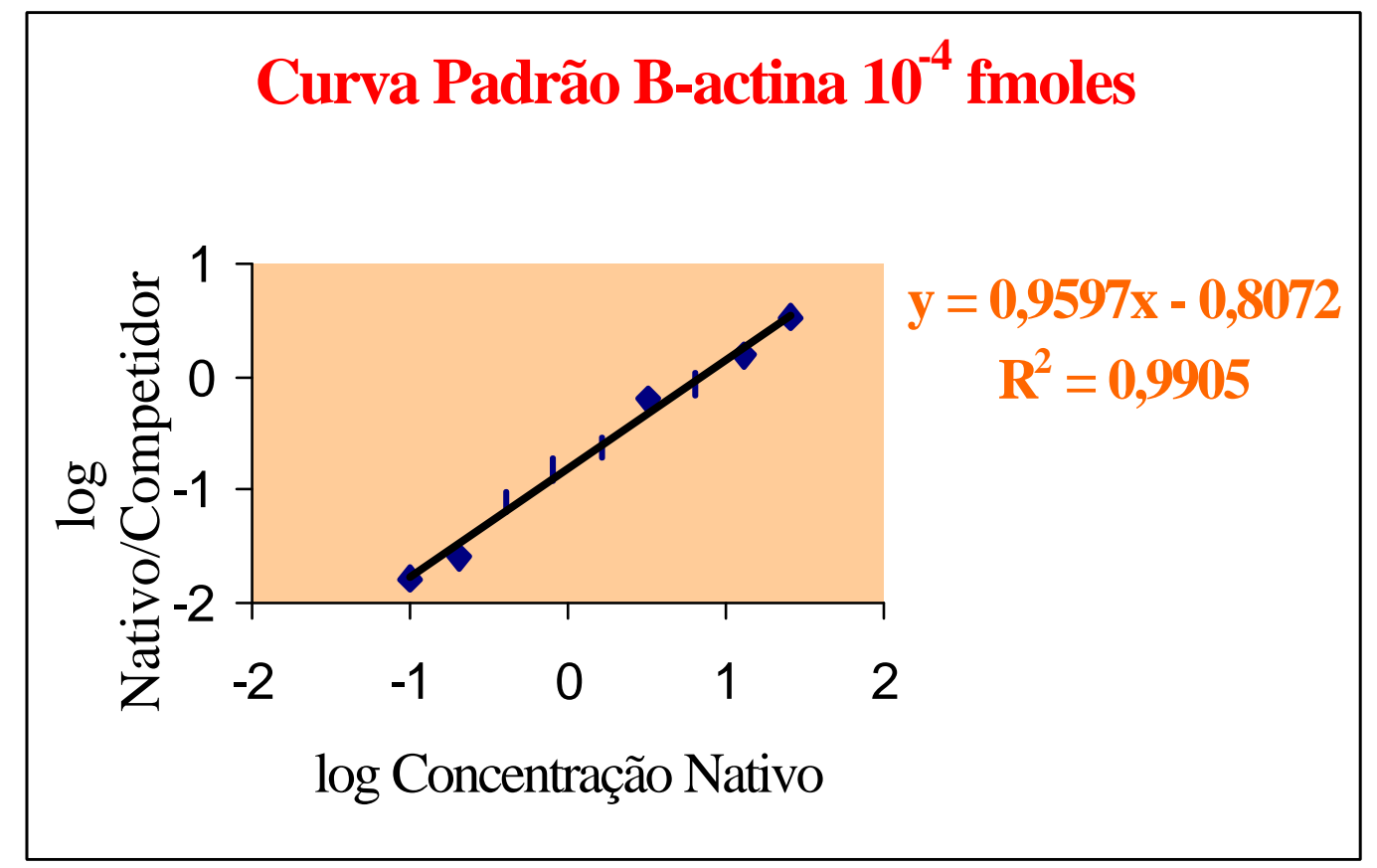

Figura 9 - Representação gráfica da curva padrão para o gene da $\beta$-actina na faixa de $10^{-4}$ fmoles. Os valores obtidos das áreas dos picos nativo e competidor, em cada faixa de diluição, foram plotados graficamente em escala logarítmica.

\subsection{Efeito da somatotropina na expressão gênica da FAS}

Após realização da quantificação do gene da $\beta$-actina na faixa de $10^{-4}$ fmoles, uma alíquota de $2 \mu \mathrm{l}$ de cada produto de PCR foi submetida à eletroforese em sequenciador automático A.L.F. Na figura 10, são representadas as bandas do fragmento de $\beta$-actina competidor e nativo (DNA dos animais), de 3 animais, submetidos aos tratamentos com pST e controle. Observa-se que o animais controle possuem as bandas do fragmento nativo (banda superior) mais intensas do que a do competidor.

Os resultados de quantificação obtidos, e determinados pelas áreas dos picos dos fragmentos competidor e nativo (DNA de interesse), foram calculados em relação à curva padrão obtida para o gene da $\beta$-actina. 


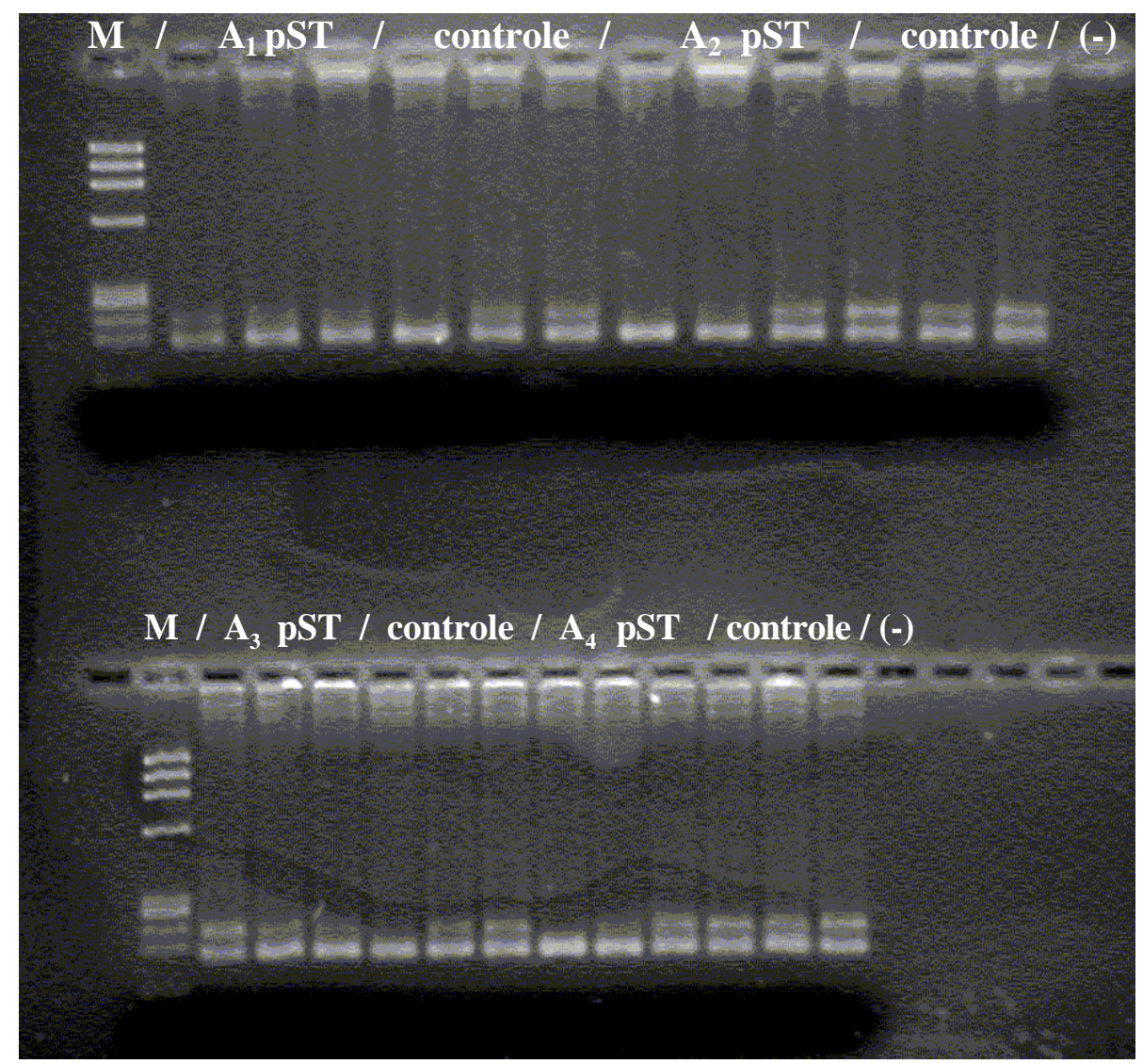

Figura 10 - Visualização em gel de agarose 3\% corado com brometo de etídeo, da quantificação de três animais, submetidos aos tratamentos com pST e controle para o gene da $\beta$-actina. As últimas canaletas representam o controle negativo.

As bandas do fragmento competidor e nativo (DNA dos animais), do tecido adiposo de 3 animais submetidos aos tratamentos com pST e controle pode ser visualizada na figura 11. Observa-se que os tecidos controle (insulina e dexametasona) possuem as bandas do fragmento nativo (banda superior) mais intensas do que a do competidor. A abundância de mRNA da FAS, para os tecidos tratados com pST, mostra-se em menor quantidade do que para o controle.

Uma alíquota de $2 \mu 1$ de cada produto de PCR, foi submetida à eletroforese em sequenciador automático A.L.F. Os resultados de quantificação obtidos no A.L.F., e determinados pelas áreas dos picos dos fragmentos competidor e nativo (DNA de interesse), foram calculados em relação a curva- padrão obtida para o gene da FAS. 


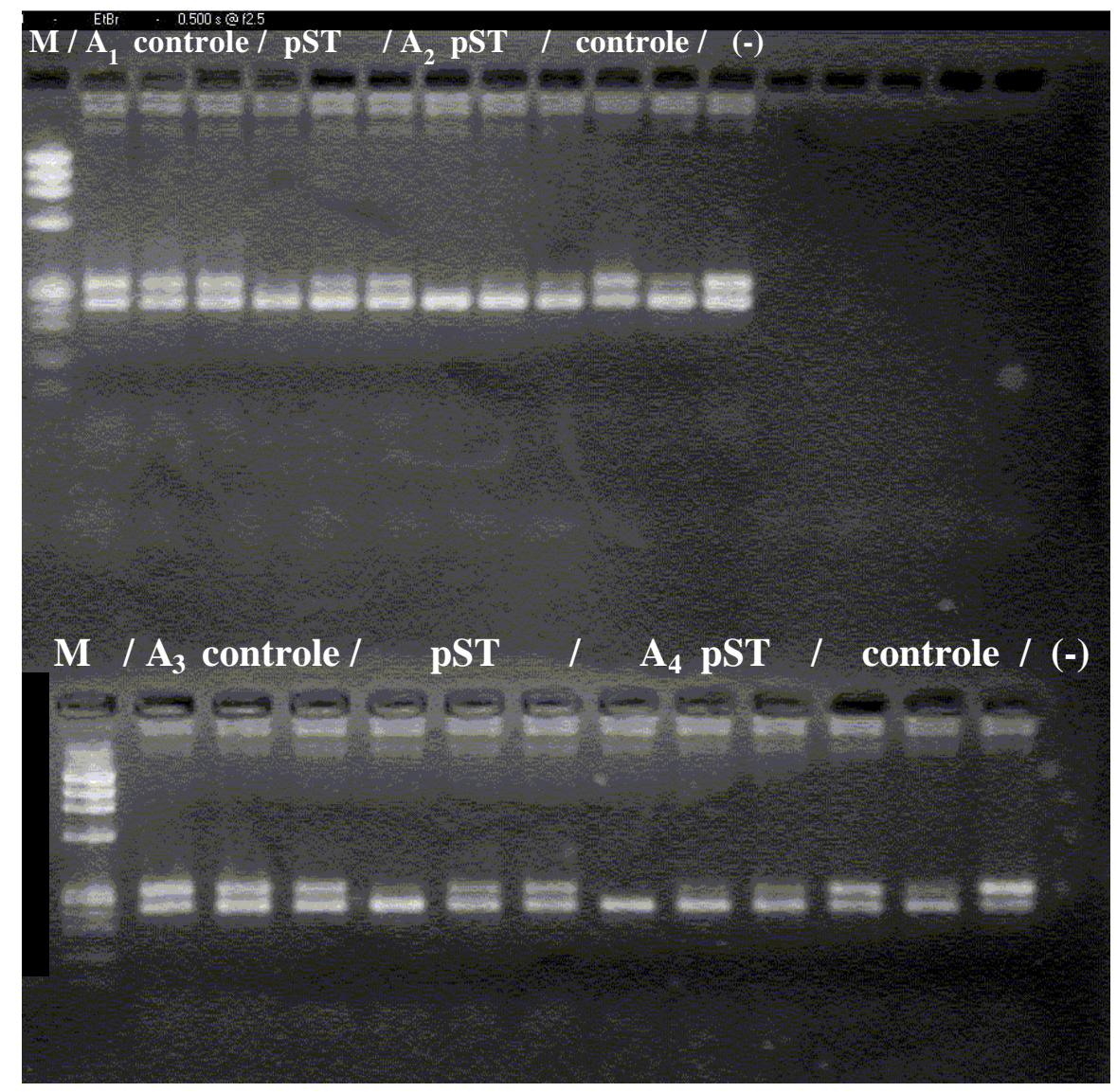

Figura 11 - Visualização em gel de agarose 3\% corado com brometo de etídeo, da quantificação da FAS em três animais submetidos ao tratamento com pST e controle. As últimas canaletas representam o controle negativo.

Na tabela 1 observam-se os resultados estatísticos obtidos do efeito do pST na abundância de mRNA dos genes da $\beta$-actina, FAS e FAS corrigida para os valores de $\beta$-actina. 
Tabela 1. Efeito da somatotropina na abundância de mRNA, nas culturas de tecido adiposo, incubadas por $48 \mathrm{~h}$ na presença de diferentes tratamentos hormonais.

\begin{tabular}{|c|c|c|c|c|}
\hline \multicolumn{5}{|c|}{ TRATAMENTOS $^{2}$} \\
\hline Genes & $I N S+D E X$ & $I N S+D E X+p S T$ & $E P M^{3}$ & $P^{4}$ \\
\hline$\beta$ - actina & 1,99 & 1,67 & $\mathbf{0 , 3 3}$ & 0,11 \\
\hline FAS & $9,8^{a}$ & $3,9^{b}$ & 0,21 & $\mathbf{0 , 0 5}$ \\
\hline FAS ${ }^{1}$ & $9,8^{\mathrm{a}}$ & $5,9^{b}$ & 0,22 & $\mathbf{0 , 0 5}$ \\
\hline \multirow{2}{*}{\multicolumn{5}{|c|}{$\begin{array}{l}\text { Valores x } 10^{-4} \text { fentomoles. } \\
{ }^{1} \text { valor de FAS já corrigido para } \beta \text {-actina. }\end{array}$}} \\
\hline & & & & \\
\hline \multicolumn{5}{|c|}{${ }^{2} \mathrm{INS}, 100 \mathrm{ng} / \mathrm{ml}$ de insulina; DEX, $10 \mathrm{nM}$ de dexametasona; $\mathrm{pST}, 100 \mathrm{ng} / \mathrm{ml}$ de somatotropina. } \\
\hline \multicolumn{5}{|c|}{3 EPM: erro padrão das médias para observação pareada (Minitab, 2000). } \\
\hline
\end{tabular}

Foi observada uma redução na abundância de mRNA da FAS, em culturas primárias de tecido adiposo subcutâneo de suínos, incubados por 48 horas com o tratamento contendo insulina, dexametasona e pST, em comparação com o Controle, com apenas insulina e dexametasona.

O presente estudo corrobora trabalhos com animais in vivo (Harris et al., 1993; Mildner \& Clarke, 1991; Donkin et al.,1996a; 1996b; Yin et al., 1998) demonstrando redução na abundância de mRNA da FAS da ordem de 40\%, sugerindo uma redução na expressão gênica, devido à ação da somatotropina (Tabela 1). Estudos com tratamento in vivo e avaliações in vitro, onde foram observadas as influências do pST na taxas de lipogênese, (Harris et al., 1993) afirmam, novamente, que há uma forte influência sobre a expressão gênica das enzimas responsáveis pela lipogênese, especialmente a FAS. Para a ACC, sabe-se que há uma redução na quantidade total desta enzima em bovinos e monogástricos (Lanna et al., 1995; Bauman \& Vernon, 1993).

Wang et al., (1999) observaram, em culturas de tecido adiposo de suínos, que a habilidade da somatotropina, em inibir a síntese de lipídeos, requer mais de 4 horas para começar a se manifestar. Este intervalo reflete o tempo requerido para a somatotropina decrescer a expressão de algum gene envolvido na lipogênese, já que a actinomicina D impede a abservação dos efeitos da ST. Os 
efeitos, provavelmente, envolvem a redução na expressão das enzimas como a FAS e ACC, ou ainda de algum fator envolvido na tradução do sinal que ativa a lipogênese. Devido a longa meia vida das enzimas citadas, os efeitos de mais curto prazo (4-8 horas) devem envolver os componentes da via sinalizadora de ativação das enzimas enquanto no longo prazo (24-72 horas) o efeito deve estar mais ligado à redução da abundância das enzimas em si.

\subsection{Ensaio da atividade enzimática da FAS}

A tabela 2 demonstra os efeitos da somatotropina na atividade enzimática da FAS. Nas culturas de tecido adiposo, incubadas por 48 horas com pST, houve uma redução na atividade da FAS $(\mathrm{P}<0,05)$. Estes resultados foram condizentes com dados de literatura inclusive na sua magnitude, mesmo nos trabalhos em que foram utilizados tratamentos in vivo com pST. Harris et al., (1993), Donkin, et al., (1996a), e Lee et al., (2000) observaram que explantes de tecido adiposo de suínos, obtidos após 1-4 semanas de tratamento com pST, que a atividade enzimática da sintetase de ácidos graxos era reduzida de 40-80\%. Lanna et al., (1994) também trataram os explantes de tecido adiposo in vitro por 48 horas e observaram reduções similares na atividade da FAS. Outros trabalhos demonstraram a redução na abundância (Harris et al. 1993; Donkin et al., 1996a) e estabilidade do mRNA (Yin et al., 1998) e, consequentemente, a capacidade do tecido adiposo para sintetizar lipídeos medida através da incorporação de glucose marcada (Harris et al., 1993; Lanna et al., 1994). 
Tabela 2. Efeito da somatotropina na atividade da FAS, em culturas de tecido adiposo, incubadas por $48 \mathrm{~h}$ na presença de diferentes tratamentos hormonais.

\begin{tabular}{lcccc} 
& \multicolumn{2}{c}{ TRATAMENTOS $^{2}$} & & \\
Enzima & $I N S+D E X$ & $I N S+D E X+p S T$ & $E P M^{3}$ & $P^{4}$ \\
& & & & \\
& $\mathbf{4 6 , 4}^{\text {a }}$ & $\mathbf{3 5 , 8} \mathbf{8}^{\mathbf{b}}$ & $\mathbf{9 , 0 7}$ & $\mathbf{0 , 0 5}$ \\
$\begin{array}{l}\text { graxe de ácidos } \\
\text { graxos }^{1}\end{array}$ & & & & \\
\hline
\end{tabular}

${ }^{1}$ Valores de atividade da FAS expressos em nmoles de substrato (NADPH) transformado em NADP por min e mg de proteína.

2 INS, $100 \mathrm{ng} / \mathrm{ml}$ de insulina; DEX, $10 \mathrm{nM}$ de dexametasona; pST, $100 \mathrm{ng} / \mathrm{ml}$ de somatotropina.

${ }^{3}$ EPM: desvio padrão das médias para observação pareada (Minitab, 2000).

${ }^{4} \mathrm{a} / \mathrm{b}$ : valores seguidos de letras distintas na mesma linha, diferem estatisticamente. $(\mathrm{P}<0,05), \mathrm{n}=5$. 
A regulação da expressão gênica das enzimas chaves, na síntese de lipídeos, é controlada por diversos fatores como estado nutricional, composição da dieta com diferentes proporções de carboidratos e gorduras, do perfil e grau de saturação dos ácidos graxos e de efeitos hormonais. A somatotropina e a insulina têm efeito pivotal na regulação da lipogênese e, entre outros efeitos, a somatotropina parece ter um efeito antagônico à insulina (Bauman \& Vernon, 1993).

O tecido adiposo é um dos tecidos que mais responde à insulina, os adipócitos dependem da difusão facilitada para a entrada de glucose, um processo estimulado pela insulina e estas células são muito pouco permeáveis à glucose na ausência deste hormônio. Os mecanismos, envolvidos no efeito antilipolítico da insulina, não são totalmente conhecidos, mas incluem redução na concentração intracelular do cAMP (adenosina 3', 5'- monofosfato cíclico) produzido pela Adenilato Ciclase, estimulação da Fosfodiesterase de baixo $\mathrm{Km}$ e de Fosfatases que defosforilam e inativam a enzima Lipase Sensível a Hormônio, responsável pela lipólise. Neste trabalho, podemos observar que em culturas de tecido adiposo que foram submetidas ao tratamento conjunto de insulina e pST, houve uma pronunciada diminuição na expressão gênica da sintetase de ácidos graxos, observada tanto na atividade enzimática total $(\mathrm{P}<0,05)$, como na abundância de mRNA $(\mathrm{P}<0,05$ e redução de $40 \%)$.

Segundo Donkin et al., (1996b) existem dois mecanismos pelos quais o pST pode antagonizar o efeito biológico da insulina na transcrição gênica da FAS. Um deles seria pela ruptura na sinalização da insulina no gene; isto diminuiria a ativação de um ou de todos os supostos fatores de ação trans que interagem com os elementos de ação cis de resposta a insulina (IRE) que conferem regulação positiva na transcrição gênica da FAS. O outro é que um distinto elemento de resposta à somatotropina (STRE), no gene da FAS, agiria como um elemento de controle negativo, existindo uma evidência de que este elemento pode estar presente no gene. 
A partir destas observações, torna-se mais evidente a necessidade de se observar como estes mecanismos de resposta à insulina são bloqueados ou até mesmo inibidos pela ação da somatotropina. Surgem dúvidas se estes mecanismos estão localizados diretamente dentro de um IRE, ou se existem outros meios de ligação que são interrompidos. Várias pesquisas têm sido conduzidas para observação deste efeito antagônico, sugerindo a utilização de conhecimento de outros genes e seus receptores ligados a esta cascata sinalizadora. O estabelecimento da técnica de avaliação in vitro, validado neste trabalho, permite que estudos mais aprofundados das seqüências promotoras sejam realizados no futuro.

Além do trabalho conduzido com culturas de tecido primárias demonstrado neste trabalho, também as linhagens de adipócitos como a 3T3-F442A têm sido utilizadas para observações do efeito de diversos tratamentos incluindo da somatotropina (Yin et al., 1998). Estes autores indicam o uso da linhagem celular 3T3-F442A como um modelo de células apropriado para uso na investigação do efeito antagônico da somatotropina na insulina. Observaram uma redução de 40 a $70 \%$ na abundância de mRNA da FAS que foi próxima à observada neste trabalho. Entretanto, linhagens de células como a 3T3-F442A apresentam diversos aspectos do metabolismo diferentes de células in vivo, incluindo o fato de serem imortais. Portanto, apesar da concordância dos resultados para a abundância de mRNA da FAS, os dados observados com linhagens de células devem ser analisados com cautela.

Os resultados deste trabalho também demonstram uma alta correlação entre os resultados obtidos em estudos in vivo e in vitro. Neste trabalho, pôde-se observar que nas culturas que receberam pST, houve um decréscimo na abundância de mRNA da FAS $(\mathrm{P}<0,05)$ bem como na atividade enzimática ( $\mathrm{P}<0,05)$, enquanto Harris et al., (1993), observaram correlação de atividade e abundância $(\mathrm{R}=0,9)$ de mRNA da FAS, em tecido adiposo de suínos tratados in vivo, e que mudanças na atividade enzimática da FAS estão altamente correlacionadas a mudanças na abundância de seu mRNA.

Donkin et al., (1996a), observaram em suínos que receberam pST in vivo, que a somatotropina tendeu a um acréscimo, não significativo $(\mathrm{P}=0,38)$, na abundância de mRNA da $\beta$ actina. Neste estudo, porém, a administração de pST in vitro, causou uma tendência de diminuição da abundância de mRNA para este gene $(\mathrm{P}=0,11)$. Como a $\beta$-actina foi utilizada como fator de 
controle interno, há necessidade de se ampliar o estudo do efeito da ST sobre este gene, bem como de outros genes constitutivos.

Com a utilização de culturas primárias de tecido adiposo subcutâneo poderão ser conduzidas grandes quantidades de tratamentos, para observação dos efeitos da somatotropina, tanto na lipogênese como na lipólise. Estudos mais aprofundados dos mecanismos pelos quais a ST antagoniza os efeitos da insulina serão possíveis permitindo a avaliação de elementos de resposta e dos fatores de transcrição envolvidos. 


\section{CONCLUSÕES}

Sendo a somatotropina uma importante coordenadora do direcionamento de nutrientes para os diferentes tecidos corporais de importância na produção animal, torna-se necessária a compreensão de seus mecanismos de ação, como a regulação da expressão gênica de enzimas responsáveis pela síntese de gordura no tecido adiposo. $\mathrm{O}$ grande progresso no entendimento dos efeitos biológicos da somatotropina em animais domésticos é, em parte, função dos avanços na biologia molecular que tornou viável a produção de grandes quantidades de somatotropina recombinante (bST e pST) e o desenvolvimento das técnicas que permitem o estudo da fisiologia celular. Esta disponibilidade de ST resultou em um acréscimo exponencial nas investigações que exploraram seu papel na regulação do crescimento e da lactação, bem como permitiram o seu uso comercial (Etherton \& Bauman, 1998).

Os resultados deste trabalho demonstram que o tratamento crônico com somatotropina reduz a expressão gênica da enzima lipogênica sintetase de ácidos graxos no tecido adiposo de suínos, submetidos à cultura de tecido. Os dados são consistentes com a redução na atividade total da enzima medida nos mesmos explantes.

Estes resultados foram observados através da técnica de RT-PCR Quantitativa Competitiva que foi padronizada e validada em um modelo de cultura primária de explantes de tecido adiposo subcutâneo. Com a utilização desta técnica demonstrourse que a redução da atividade enzimática é acompanhada de uma redução na abundância do mRNA da FAS. Estes dados são consistentes com a literatura, onde estudos com tratamento in vivo observaram reduções de similar magnitude.

No presente trabalho, verificourse que a somatotropina tendeu a causar uma redução na expressão gênica do gene da $\beta$-actina, nas culturas primárias de tecido adiposo subcutâneo. Estes resultados sugerem que, no futuro, outros genes constitutivos sejam estudados para efeito de correções e também para observar possíveis fatores que podem influenciá-los. 
A padronização e validação do uso combinado das técnicas de cultura primária de explantes de tecido adiposo e RT-PCR Quantitativa Competitiva abre novas possibilidades para o estudo de outros mecanismos de ação no metabolismo animal, envolvendo ou não a ST, incluindo uma gama de tratamentos hormonais e nutricionais responsáveis pelo controle da deposição de gorduras em animais em crescimento. 

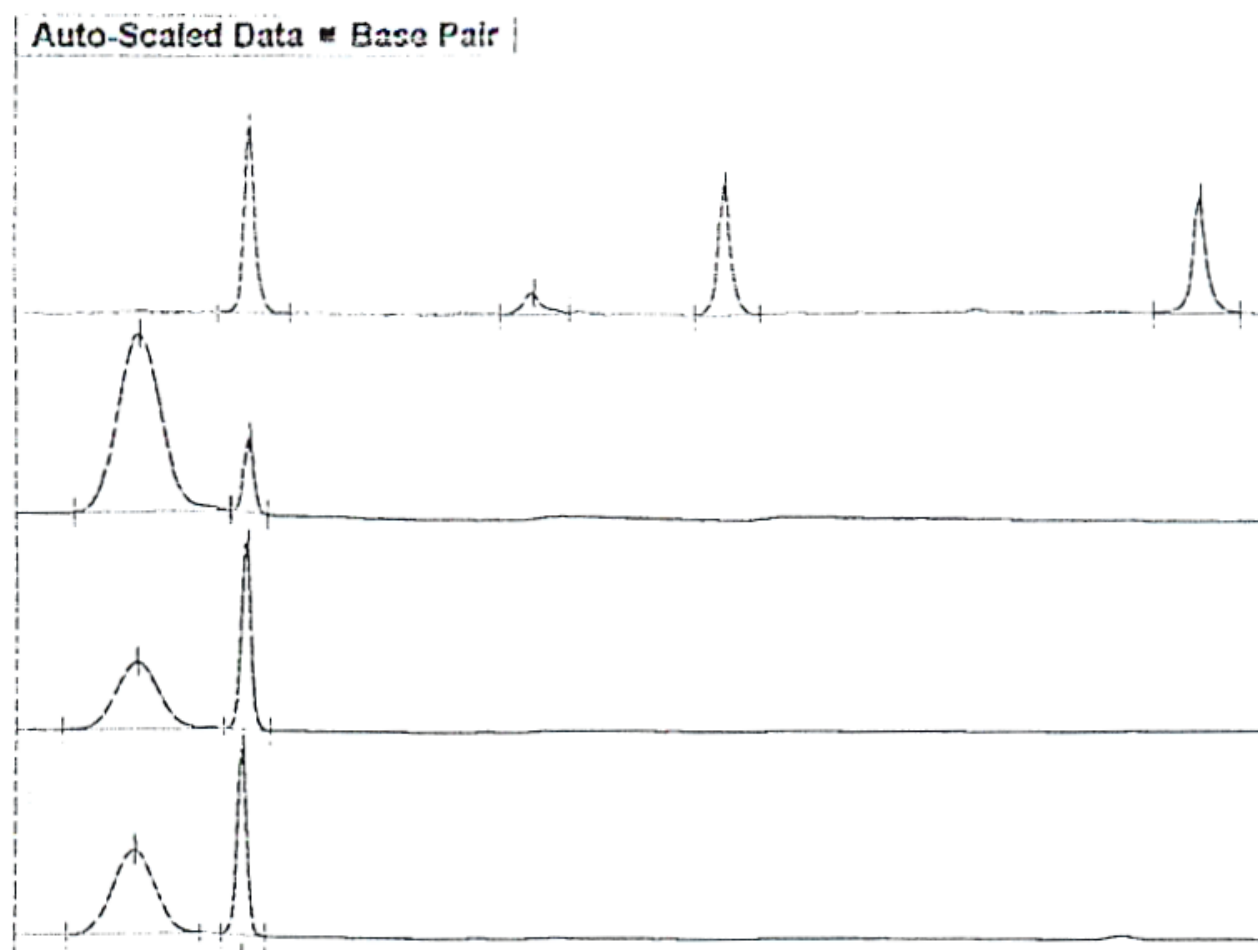

Competidor $243 b p$

Nativo 307bp

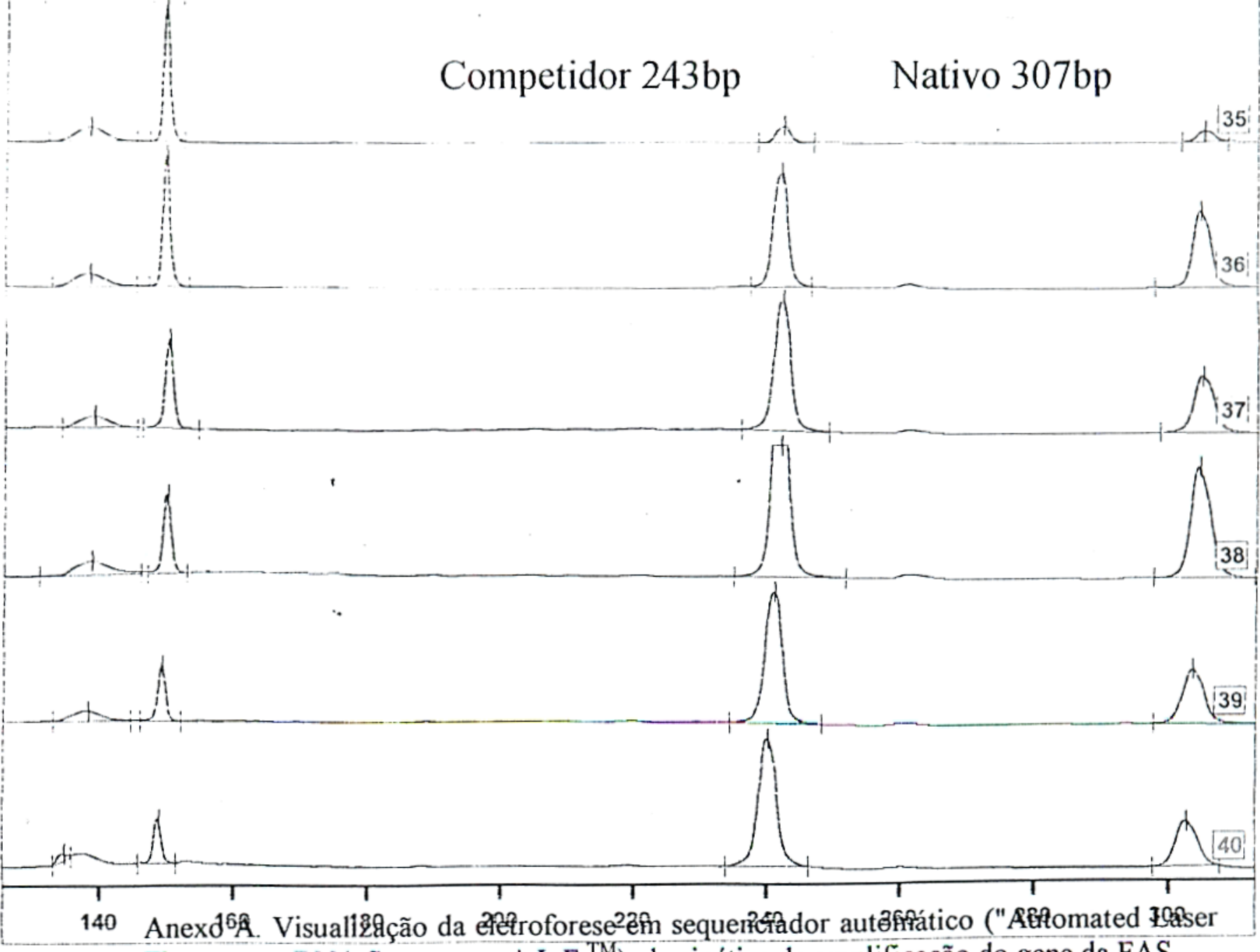
Fluorescent DNA Sequencer- A.L.F. ${ }^{\text {TM }}$ ), da cinética de amplificação do gene da FAS. 


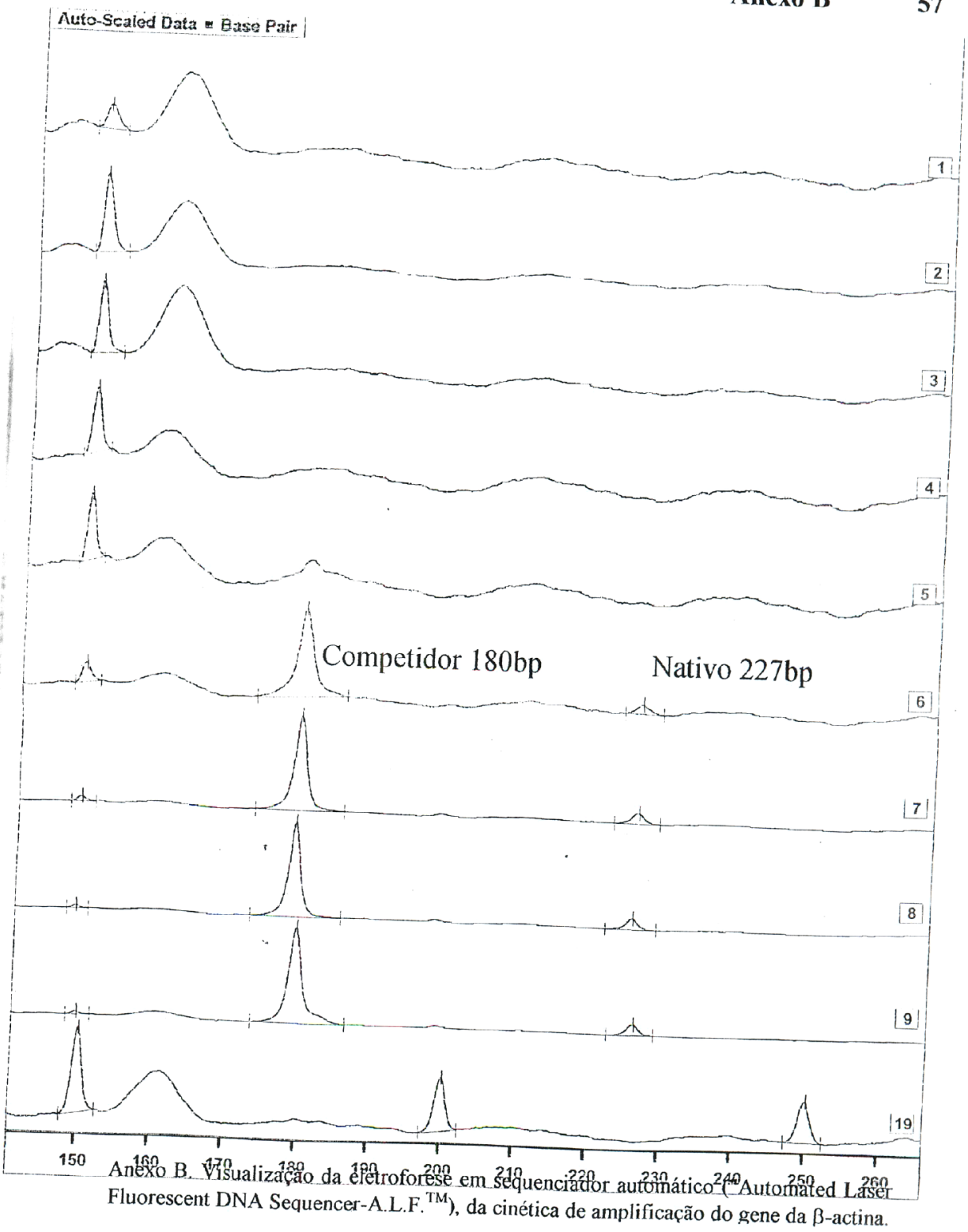


26/.11:1100 16:33:35

C:IAMDATAIC0298.ALF

Auto-Scaled Data - Base Pair

Pharmacia DHA Fragment Manager V1.2

Page 1

Anexo C

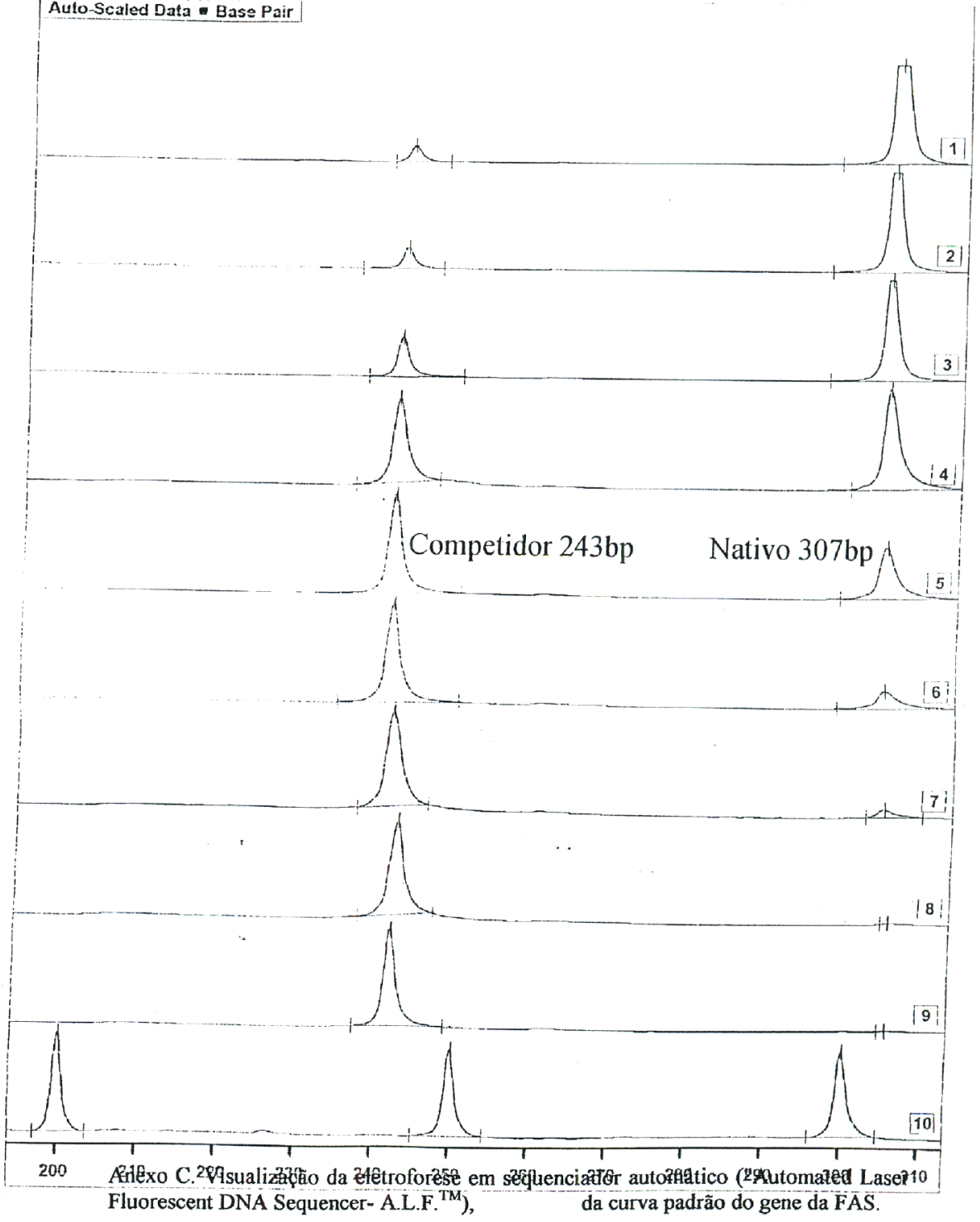




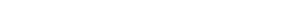

\section{Anexo D}

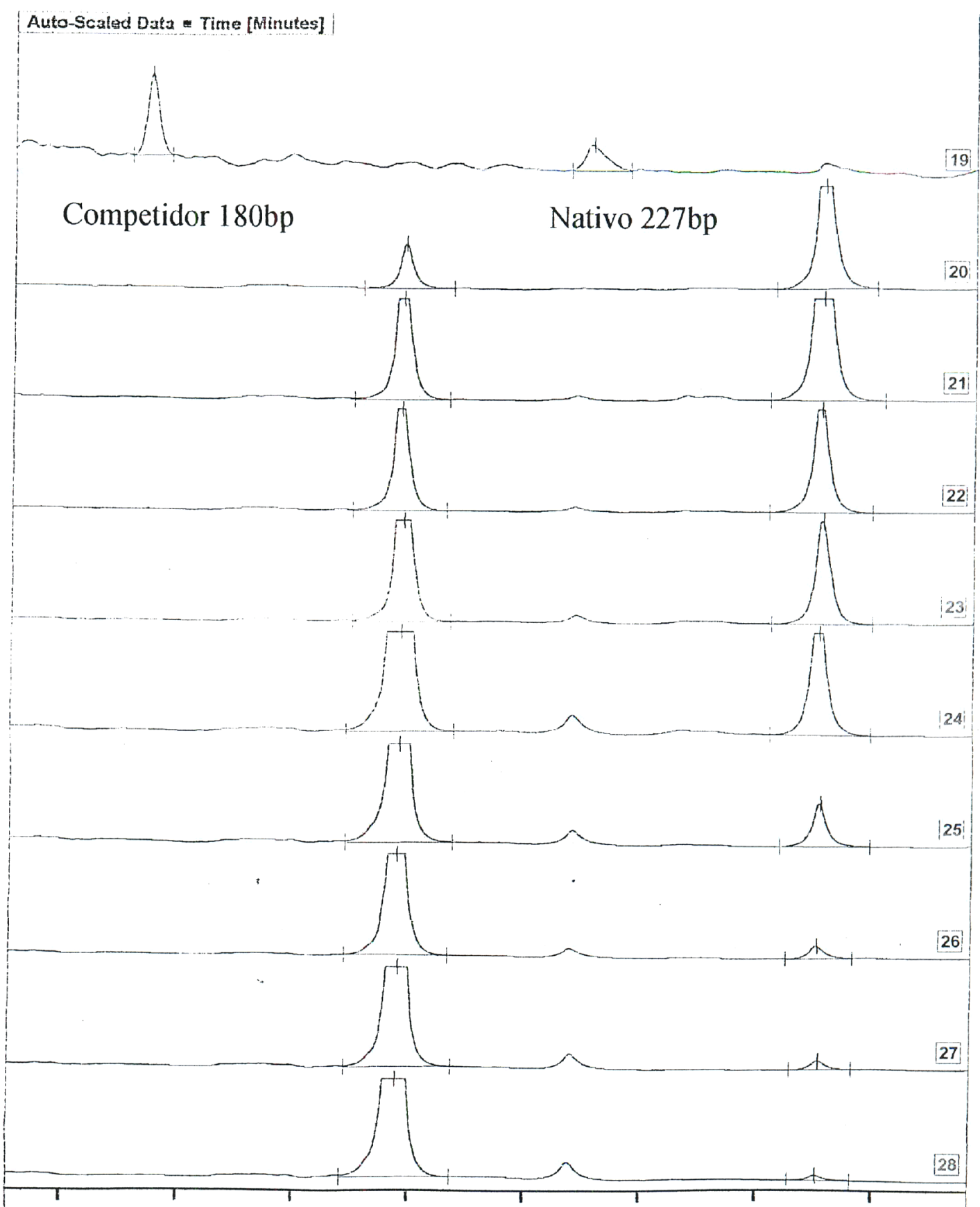

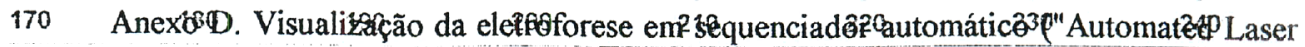
Fluorescent DNA Sequençer- A.L.F. ${ }^{\text {TM }}$ ), da curva padrão do gene da $\beta$-actina. 


\section{REFERÊNCIAS BIBLIOGRÁFICAS}

BAUMAN, D.E. Intermediary metabolism of adipose tissue. Federation Proceedings, v.35, p. 2308-2313, 1976.

BAUMAN, D.E. Bovine somatotropin and lactation: from basic science to commercial application. Domestic Animal Endocrinology, v. 17, p. 101-116, 1999.

BAUMAN, D.E.; CURRIE, W.B. Partitioning of nutrients during pregnancy and lactation: A review of mechanisms involving homeostasis and homeorhesis. Journal of Dairy Science, v.63, p.1514-1529, 1980.

BAUMAN, D.E.; MCCUTCHEON, S.N.; STEINHOUR, W.D.;. EPPARD, P.J.; SECHEN, S.J.. Sources of variation and prospects for improvement of productive efficiency in the dairy cow: a review. Journal of Animal Science v.60, p.583-592, 1985.

BAUMAN, D.E.; VERNON, R.G. Effects of exogenous bovine somatotropin on lactation. Annual Review Nutrition, v. 13, p. 437-461, 1993.

BORLAND, C.A.; BARBER, M.C.; TRAVERS, M.T.; VERNON, R.G. Growth hormone inhibition of lipogenesis in sheep adipose tissue: requirement for gene transcription and polyamines. Journal Endocrinology, v. 142, p. 235-243, 1994.

BOYD, R.D., BAUMAN. D.E. Mechanisms of action for somatotropin in growth. In: Campion, D.R.; Hausman, G.J.; Martin, R.J. Current Concepts of Animal Growth Regulation. New York: Plenum Publishing Corp., 1989, p. 257-293.

CLARKE, S.D. Regulation of fatty acid synthase gene expression: an approach for reducing fat accumulation. Journal of Animal Science, v. 71, p. 1957-1965, 1993.

CLARKE, S.D. Nutrient regulation of gene expression: a methodological strategy. Mineral and Electrolyte Metabolism, v. 23, p. 130-134, 1997. 
CLARKE, S.D., JUMP, D.B. Regulation of gene transcription by polyunsaturated fatty acids. Progress on Lipids Research, v. 32, p. 139-149, 1993.

DONKIN, S.S.; CHIU, P.Y.; YIN, D.; LOUVEAU, I.; SWENCKI, B.; VOCKROTH, J. EVOCKCLOVER, C.M.; PETERS, J.L.; ETHERTON, T.D. Porcine somatotropin differentially downregulates expression of the GLUT4 and Fatty Acid Synthase genes in pig adipose tissue. Journal Nutrition, v. 126, p. 2568-2577, 1996a.

DONKIN, S.S.; McNALL, A.D.; SWENCKI, B.S., PETERS, J.L., ETHERTON, T.D. The growth hormone - dependent decrease in hepatic fatty acid synthase mRNA is the result of decrease in gene transcription. Journal of Molecular Endocrinology, v. 16,p. 151-158, 1996 b.

ETHERTON, T.D.; BAUMAN, D.E. Biology of somatotropin in growth and lactation of domestic animals. Physiological Reviews, v. 78, p. 745-761, 1998.

ETHERTON, T.D.; LOUVEAU, I. Manipulation of adiposity by somatotropin and $\beta$-adrenergic agonists: a comparison of their mechanisms of action. Proceedings of the Nutrition Society, v. 51, p. 419-431, 1992.

ETHERTON, T.D.; DONKIN, S.S.; BAUMAN, D.E. Mechanisms by which porcine somatotropin (pST) decreases adipose tissue growth in growing pigs. In: SMITH, S.B.; SMITH, D.R.; CHAMPAIGN, IL. The Biology of Fat in Meat Animals. Am. Soc. Anim. Sci., 1995, p. 53-69.

GIRARD, J.; CHATELAIN, F., BOILlOT, J.; PRIP-BUUS, C.; THUMELIN, S.; PÉGORIER, JP.; FOUFELLE, F.; FÉRRE, P. Nutrient regulation of gene expression. Journal of Animal Science, v. 75, p. 46-57, 1997.

GORNALL, A.G.; BRADAWILL, C.T.; DAVID, M.M. Determination of serum protein by means of biuret reagent. Journal of Biological Chemistry, v. 177, p. 751-766, 1949.

HANAHAN, D. Studies on transformation of Escherichia coli with plasmids. Journal Molecular Biology, v. 166, p. 557-580, 1983.

HARRIS, D.M.; DUNSHEA, F.R.; BAUMAN, D.E.; BOYD, R.D.; WANG, S.Y. JOHNSON, P.A.; CLARKE, S.D. Effect of in vivo somatotropin treatment of growing pigs on adipose tissue lipogenesis. Journal of Animal Science, v. 71, p. 3293-3300, 1993. 
LANNA, D.P.D., DWYER, D.A.; BAUMAN, D.E. Somatotropin and the control of lipogenesis by insulin and adenosine in pig adipose tissue. Journal of Animal Science, v. 72, p. 161, 1994.

LANNA, D.P.D.; HOUSEKNECHT, K.L.; HARRIS, D.M.; BAUMAN, D.E. Effects of somatotropin treatment on lipogenesis, lipolysis and related cellular mechanisms in adipose tissue of lactating cows. Journal of Dairy Science, v. 78(8), p. 1703-1712, 1995.

LANNA, D.P.D.; BAUMAN, D.E. Effect of somatotropin, insulin, and glucocorticoid on lipolysis in chronic cultures of adipose tissue from lactating cows. Journal of Dairy Science, v. 82, p. 60-68, 1999.

LEE, K.C.; AZAIN, M.J.; HUSMAN, D.B.; RAMSAY, T.G. Somatotropin and adipose tissue metabolism: substrate and temporal effects. Journal of Animal Science, v. 78, p. 1236-1246, 2000 .

LESSARD, M.; HE, S.; BENKEL, B. A quantitative reverse transcription-polymerase chain reaction technique to measure porcine interferon-gamma. Journal of Animal Science, v. 76, p. 2155-2161, 1998.

MELLENBERGER, R.W.; BAUMAN, D.E.; NELSON, D.R. Metabolic adaptations during lactogenesis. Fatty acid and lactose synthesis in cow mammary tissue. Biochemical Journal, v. 136, p. 741-748, 1973.

MILDNER, A.M.; CLARKE, S.D. Porcine fatty acid synthase: cloning of a complementary DNA, tissue distribution of its mRNA and suppression of expression by somatotropin and dietary protein. Journal Nutrition, v. 121, p. 900-907, 1991.

MINITAB STATISTICAL SOFTWARE. Ryan, B.F.; Joiner, B.L.; Ryan Jr, T.A. PWS-Ketn Publishing Company Boston $13^{\text {a }}$ Edição, 2000.

MULARIONI, A.; ADESSI, G.L.; ARBEZ-GINDRE, F.; AGNANI, G.; NICOLLIER, M. Competitive RTPCR to quantify CFTR mRNA in human endometrium. Clinical Chemistry, v. 42, p.1765-1769, 1996.

RENTSCH, J.; CHIESI, M. Regulation of $o b$ mRNA levels in cultured adpocytes. FEBS Letters, v. 379, p. 55-59, 1996.

REPP,R.; BORKHARDT, A.; GOSSEN, R.; KREUDER, J.; HAMMERSMANN, J.; LAMPERT, F. Construction of RNA standards for high-resolution automatic product analysis in quantitative competitive RT-PCR, Biotechniques, v.19, p. 84-90, 1995. 
SINNETT-SMITH, P.A.; VERNON, R.G.; MAYER, R.J. Fatty acid synthesis and the activities of fatty acid synthesizing in rat adipose tissue during pregnancy and lactation. Biochemical Society Transactions, v.7(2), p. 388-389, 1979.

TOWLE, H.C.; KAYTOR, E.N.; SHIH, H. Regulation of the expression of lipogenic enzyme genes by carbohydrate. Annual Review of Nutrition, v. 17, p. 405-433, 1997.

TSAI, SJ.; WILTBANK, M.C. Quantification of mRNA using competitive RT-PCR with standard curve methodology. Biotechniques, v. 21, p. 862-866, 1996.

TUGGLE, C.K.; TRENKLE, A. Control of growth hormone synthesis. Domestic Animal Endocrinology, v.13, p. 1-33, 1996.

VERNON, R.G.; FINLEY, E. Roles of insulin and growth hormone in the adaptations of fatty acid synthesis in white adipose tissue during the lactation cycle in sheep. Biochemical Journal, v. 256, p. 873-878, 1988.

VERNON, R.G.; BARBER, M.C.; FINLEY, E. Modulation of the activity of acetyl-CoA carboxylase and other lipogenic enzymes by growth hormone, insulin and dexamethasone in sheep adipose tissue and relationship to adaptations to lactation. Biochemical Journal, v. 274, p. 543-548, 1991.

WAKIL, S.J. Fatty acid synthase, a proficient multifunctional enzyme. Biochemistry, v. 28, p. 45234529, 1989.

WANG, A.M.; DOYLE, M.V.; MARK, D.F. Quantification of mRNA by the polymerase chain reaction. Proceedings of National Academy Science, v. 86, p. 9717-9721, 1989.

WANG, Y.; FRIED, S.K.; PETERSEN, R.N.; SCHOKNECHT, P.A. Somatotropin regulates adipose tissue metabolism in neonatal swine. Journal of Nutrition, v.129, p. 139-145, 1999.

YIN, D.; CLARKE, S.D.; PETERS, J.L.; ETHERTON, T.D. Somatotropin-dependent decrease in fatty acid synthase mRNA abundance in 3T3-F442A adipocytes is the result of a decrease in both gene transcription and mRNA stability. Biochemical Journal, v. 331, p. 815-820, 1998. 